Article

\title{
Past-Forwarding Ancient Calamities. Pathways for Making Archaeology Relevant in Disaster Risk Reduction Research
}

\section{Felix Riede}

Centre for Environmental Humanities, Laboratory for Past Disaster Science, Department of Archaeology and Heritage Studies, Aarhus University,

Moesgård All é 20, 8270 Højbjerg, Denmark; f.riede@cas.au.dk; Tel.: +45-871-62081

Received: 13 August 2017; Accepted: 11 October 2017; Published: 26 October 2017

\begin{abstract}
Despite the alleged mastery of humans over nature, contemporary societies are acutely vulnerable to natural hazards. In interaction with vulnerable communities, these transform into catastrophes. In a deep historical perspective, human communities of many different kinds have been affected by numerous kinds of natural disasters that may provide useful data for scenario-based risk reduction measures vis-à-vis future calamities. The low frequency of high magnitude hazards necessitates a deep time perspective for understanding both the natural and human dimensions of such events in an evidence-based manner. This paper focusses on the eruption of the Laacher See volcano in western Germany about 13,000 years ago as an example of such a rare, but potentially highly devastating event. It merges Lee Clarke's sociological argument for also thinking about such very rare events in disaster planning and David Staley's notion of thinking historically about the future in order to 'past-forward' such information on past constellations of vulnerability and resilience. 'Past-forwarding' is here intended to signal the use of such deep historical information in concerns for contemporary and future resilience. This paper outlines two pathways for making archaeological information on past extreme environmental events relevant in disaster risk reduction: First, the combination of information from the geosciences and the humanities holds the potential to transform ancient hazards from matters of fact to matters of concern and, hence, to more effectively raise awareness of the issues concerned. Second, in addition to information on past calamities feeding into preparatory scenarios, I argue that the well-established outreach channels available to the humanities (museums, in particular) provide powerful platforms for communication to multiple publics.
\end{abstract}

Keywords: possibilistic thinking; historical thinking; natural hazards; risk reduction; vulnerability; scenarios; volcanism; Laacher See

\section{Introduction}

Classical Western narratives of history propose that, over time, humans have made themselves masters over nature. Since the proposition of the Anthropocene-the epoch in which cultural and natural history converge and collapse into each other (Chakrabarty 2009, 2014) and in which humans have become the dominating and largely destructive force shaping global environmental change (Crutzen and Stoermer 2000) - this narrative has taken on more apocalyptic notes (Dukes 2013; Malm and Hornborg 2014). Against the background of global climate change (Mitchell et al. 2006; Schiermeier 2011; Stott et al. 2016), extreme hydrological, meteorological and geophysical events are on the rise (Schiermeier 2012). Due to parallel socio-economic developments, the burden of loss, of both lives and livelihoods, is rising even more steeply (Schiermeier 2012; Smolka 2006). 
Operating at the interface between the natural and the social sciences/humanities, disaster risk reduction (DRR) research confronts the articulation of climate change, extreme events and politics (Kelman et al. 2015, 2017), but research funding and policy-maker attention remains strongly focused on the investigation of the hazards in question rather than striking a balance between understanding hazards and at-risk-communities at similar levels of detail and sophistication (Alexander 1995, 1997). The realization that the root causes of disasters are never entirely 'natural' is not new (O'Keefe et al. 1976), and recent reviews of this field signal important shifts toward greater attention paid to social science and humanities approaches (Barclay et al. 2015; Kelman et al. 2017; Mercer et al. 2012). This paper aims to add to this growing field by reviewing and discussing how specifically archaeology can make a contribution to environmental literacy and to enriching and strengthening resilience vis-à-vis, in particular, extreme environmental events. First, I draw on independent developments in history, disaster sociology and archaeology in order to make the argument that the deep past is relevant in relation to contemporary and future calamities. With detailed reference to one particular case study, the cataclysmic eruption of the Laacher See volcano (Eifel Volcanic Field) in present-day western Germany and its impact on contemporaneous small-scale forager communities in Europe, but also with reference to a rapidly growing body of evidence for similar long-distance impacts of other volcanic events, I illustrate how such ancient calamites can be 'past-forwarded' and so brought into play in the present. The notion of 'past-forwarding' is chosen in analogy with the fast-forwarding function found on audio and video apparatuses. It is meant to convey a rapid bridging of the substantial temporal gap between the present and the distant past.

Archaeology is concerned with understanding the peoples of the past and their histories, and as an academic subject it is predominantly placed in Faculties of Arts or Social Science. Yet, with its focus on material remains, on stratigraphies, on dating, and on the spatial dimensions of culture, archaeology—under the labels of environmental archaeology and geo-archaeology—interacts naturally with geology, as well as physical and human geography (Albarella 2001; Dincauze 2000; Evans 2002). For some time now, archaeologists have been calling for a greater involvement of the discipline with the climate change debate and with DRR (Caseldine and Turney 2010; Riede 2014a, 2014c; Riede et al. 2016b; Rockman 2012; Van de Noort 2013). Through its inherently interdisciplinary work, archaeology produces evidence-based narratives of past human-environment interactions that often command substantial public interest-and numerous workers have argued that narratives are crucial tools in translating environmental science into actionable ideas (Carter and van Eck 2014; Pancost 2017).

Learning from past disasters is neither easy nor straightforward, however (Pfister 2009b; Riede et al. 2016a; Schenk 2015; Van Bavel and Curtis 2016). I focus here on two avenues, one practical and one public: (1) past calamities as input for so-called Realistic Disaster Scenarios used for planning and policy-making; (2) past calamities as platforms for dissemination and debate on the mutual dependencies of human societies and the environment in museum settings. Much archaeological work finds its way into museums of culture history. These museums are well-visited in many countries (often with markedly higher visitor numbers than their natural history counterparts) and hence well-positioned to frame debates on climate change and human impacts. The role of museums in addressing these issues and in providing democratic platforms for debate is increasingly recognized (Cameron et al. 2013; Cameron and Neilson 2015; Rees 2017), but the full potential of specifically culture history museums here remains as yet unrealized. This paper argues that the historically informed evidence-based narratives of past natural hazards and their human impacts can be brought forward ('past-forwarded') for building realistic scenarios for future calamities, and that the use of archaeological remains provides the necessary immediacy and intimacy to more directly address and engage the consumers of these narratives.

\section{Industrial and Preindustrial Pathways to Resilience}

In disaster risk reduction research, the twin notions of vulnerability and resilience are important conceptual levers. Discussions and definitions of both terms abound (Adger 2000, 2006; Bankoff 2003; 
Birkmann 2006a, 2006b; Cutter 1996; Cutter et al. 2003; Fuchs et al. 2012; Smit and Wandel 2006; Tierney 2014; Wisner et al. 2004). In short, vulnerability indexes the potential for loss, while resilience captures a given community's or society's ability to respond to and rebuild after a given calamity. Both vulnerability and resilience are socio-ecological in their composition. The foundational American disaster sociologist, Gilbert White (White 1974) suggested a long time ago that optimal resilience in relation to natural hazards would emerge in a combination of what he termed preindustrial and industrial responses. While the latter draw their strength from robust infrastructure, technical ingenuity, communication technology and organizational acumen, the former reference traditional ecological knowledge, social relations, flexible responses and better developed notions of environmental stewardship (Table 1).

Table 1. Pre-industrial and industrial responses to natural hazards, adapted from White (1974).

According to White, only Iceland comes close to have integrated the two resilience domains.

\begin{tabular}{|c|c|c|}
\hline \multicolumn{3}{|c|}{ Response Types and Characteristics } \\
\hline & Preindustrial & Industrial \\
\hline Adjustment range & Wide & Restricted \\
\hline Relation to nature & Harmonization with & Technological control over \\
\hline Capital investment & Low & High \\
\hline Response flexibility & High & Low \\
\hline Loss perception & Perceived as inevitable & $\begin{array}{l}\text { Losses may/should be reduced by } \\
\text { government action, technology, science } \\
\text { and development }\end{array}$ \\
\hline
\end{tabular}

As White also noted, most contemporary societies have not achieved to harmoniously combine their traditional preindustrial response mechanisms with industrial ones. This is often due to recent political disruptions such as colonial interventions, the impact of epidemics or the massive displacement of people between and within macro-regions due to, for instance, urbanization and rapid industrialization. To make matters worse still, many major urban centers are located in zones directly at risk from, for instance, volcanic eruptions, compounding vulnerability (Chester et al. 2001; Small and Naumann 2001). Hence, a double-bind has emerged: many regions of the world are at risk from volcanic eruptions, but for some (the non-industrialized ones), industrial resilience measures are not an option, while for others (the industrialized ones), the integration of preindustrial resilience measures in made difficult due to the loss-more often than not through active colonial suppression - of traditional knowledge about environments and their associated risks (cf. Witham 2005). Although very much concerned with assisting those at risk or those affected by hazards, the field of North American disaster sociology so heavily influenced by White is largely ahistorical in its perspective (Lovekamp and Trainor 2013). Furthermore, White's bipartite distinction between preindustrial and industrial modes of coping glosses over the many different ways in which preindustrial societies are constituted. Importantly, it also glosses over the critical issue that not all ways of preindustrial coping are equally effective. A historical perspective can go some way towards providing an evidence-based assessment of the diversity and efficacy of preindustrial risk management and coping strategies. Historical sources and the horizon of history, however, also have their limitations: concerning low-frequency/high-magnitude events where the last occurrence may date to prior to the emergence of writing, archaeology presents the only source of information about human impacts and responses. Furthermore, for many parts of the world, historical sources simply do not go back far enough in time to capture a large number and range of hazards. Historical and archaeological sources 
on both geophysical events and human impacts archived in museums (our geo-cultural heritage) can be said to be the durable remains of preindustrial environmental knowledge.

In areas where natural hazards occur frequently, the maintenance of efficient ways of responding, of so-called 'cultures of coping' (Bankoff 2009, p. 265), is likely. In contrast, when hazards occur less frequently or when we are considering high-magnitude/low-frequency hazards, a 'disaster gap' (Pfister 2009a, p. 239) emerges that creates the illusion of false security from natural events. This discounting of major risks has been thrown into stark relief by the 2010 eruption of Eyjafjallajökull (Iceland). This eruption was small and 'ordinary' (Davies et al. 2010, p. 608) by global volcanic standards. It was, however, perceived and experienced as decidedly catastrophic by many. Although local farms were affected and although the landscape remains barren in the volcano's immediate vicinity (Figure 1), its awesome display of geological force also attracted badly-needed tourists at a time of economic troubles (Benediktsson et al. 2011). As Iceland regularly experiences eruptions, communities and authorities are able to rapidly assess and respond to the risk (cf. Gislason et al. 2011); in fact, Iceland was White's premier example of a society close to achieving the marriage of preindustrial and industrial resilience. As a result, the local effects of this eruption were minor. Yet, the ash it generated was transported to Europe with paralyzing and economically disastrous consequences (Pedersen 2010). Flights were grounded due to the threat of volcanic ash particles to aviation (Langmann et al. 2012), sparking a virtual mobility-related panic that affected millions of people in Europe and beyond (Guiver and Jain 2011; O'Regan 2011). The numbers are staggering (Budd et al. 2011): 108,000 flights were cancelled, 10.5 million passengers were affected, and the aviation industry alone suffered losses in excess of 1.5 billion Euros. How can such an insignificant geophysical event become such a calamity, and cause such costs? The answer to this question rests not in 'nature', not in the volcanological properties of the eruption. They are not unimportant, but causal in a more salient and significant way are the economic, social, and cognitive structures and systems that the eruption interacted with. European airspace is the premier hub of today's global 'aeromobility' (Figure 2; (Urry 2007, 2009)). This particular impact has stimulated a great number of studies investigating the mechanisms volcanic ash impacts on air traffic and the governance thereof (Alexander 2013; Donovan and Oppenheimer 2012; Guiver and Jain 2011). The remarkable effects of the Eyjafjallajökull eruption can therefore not be sought in its inherent, geophysical properties, but rather in the complex ways in which it interacted with the affected societies and their ways of socially, cognitively, legally and technologically handling this event (Alexander 2013; Donovan and Oppenheimer 2011, 2012, 2013; Lund and Benediktsson 2011).

In line with the eruptions of Mount St. Helens of 1980 (Carson 2000), the Parícutin eruption of 1943 (Luhr and Simkin 1993), the eruption of Pinatubo in 1991 (Gaillard et al. 2007) and a handful others (Oppenheimer 2011), the Eyjafjallajökull eruption is one of a few such event that has been comprehensively studied from both a natural and social scientific perspective. It thus serves to underline the notion that this kind of geophysical event is not to be considered causal of any kind of impact or human cultural responses in isolation, but rather that it poses as a complex of risks or hazards; a disaster then emerges at 'the interface between an extreme physical event and a vulnerable human population' (Susman et al. 1983, p. 264). In addition (and this observation is at the same time more mundane but also perhaps more critical), the Eyjafjallajökull eruption offers, owing to its remote island location, a drastically simplified distinction between near-field direct and far-field indirect impacts. Its effects underline that the nature and magnitude of hazard and impact of a given eruption change, potentially dramatically, along its fallout transect.

At first glance, it may seem paradoxical that impact increases with distance, but this is what November (November 2008, p. 1523) calls the 'spatiality of risk', where impact is not alone determined by proximity to a hazard, but by the constellations of pre-event vulnerability prevalent in the affected societies. Human populations are bound together in complex social, demographic, and economic networks that, in addition to underlying differences in local ecology conditioned by, for instance, latitudinal gradients, reflect this spatial variation. It is arguably the fragility or otherwise of these social 
networks that determine the extent of impact, and the specific structures that steer cascading effects such as those observed in the wake of the Eyjafjallajökull event (Helbing 2013; Helbing et al. 2006).

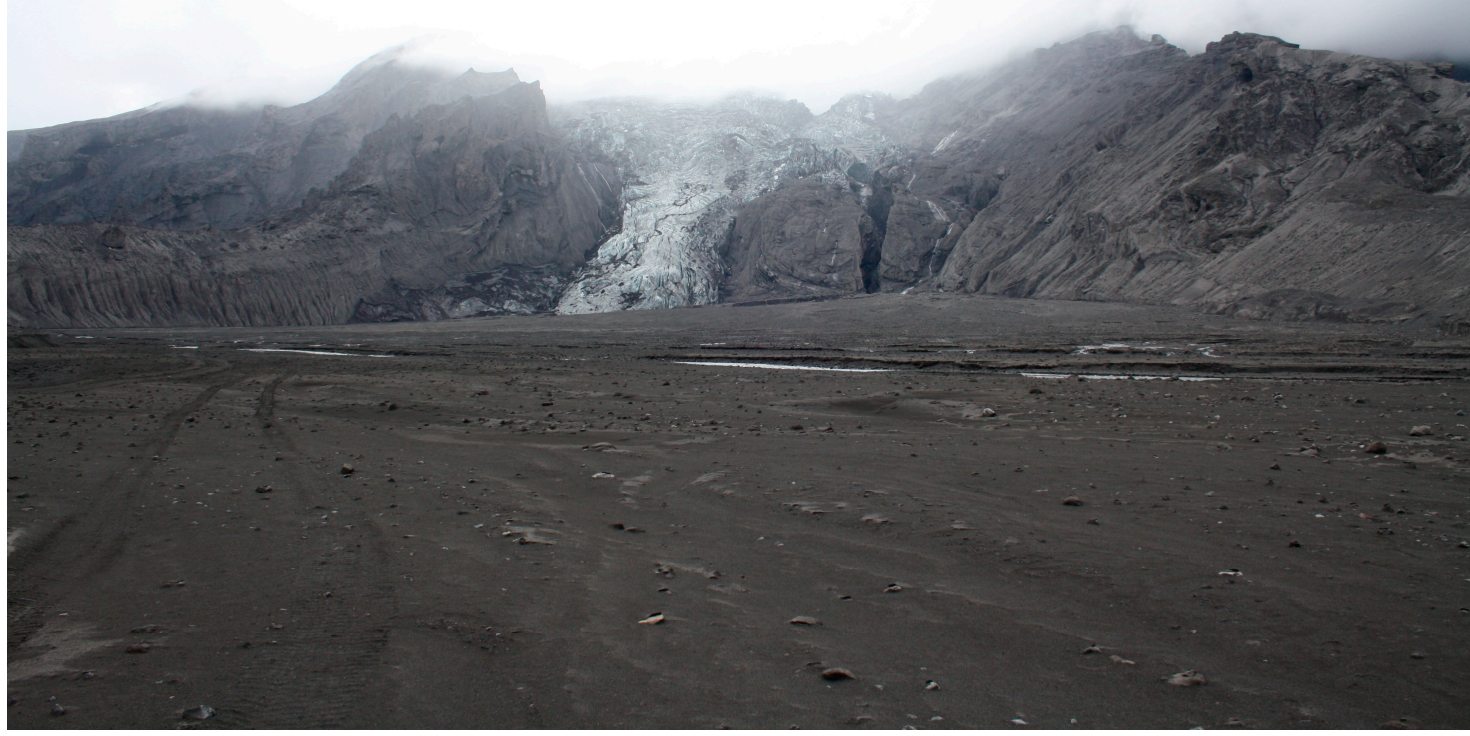

Figure 1. The area around Eyjafjallajökull some seven months after the eruption. Photo: the author.

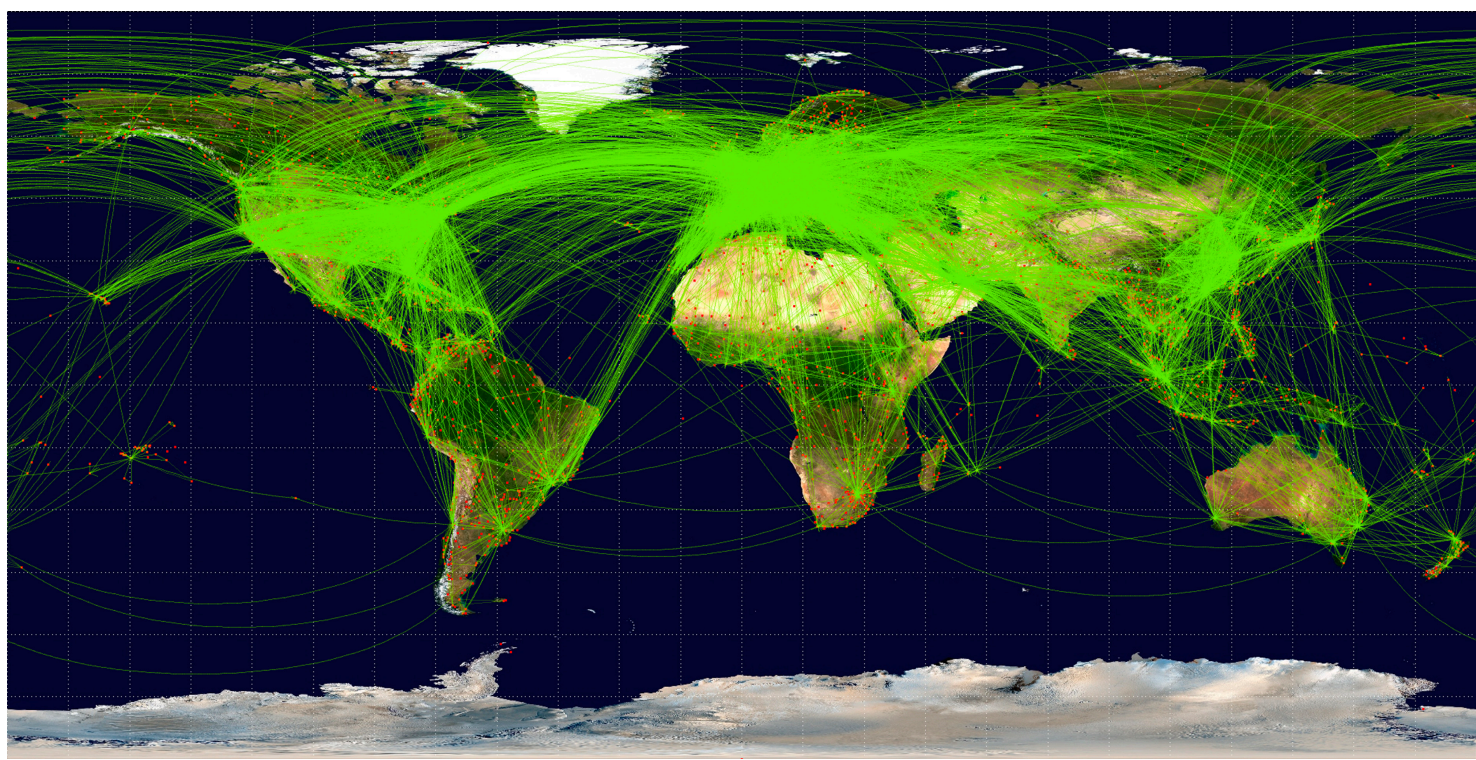

Figure 2. The global 'aeromobile' network of the present day, from http:/ / openflights.org. Note the extreme node density in Europe.

The particulars of this eruption also expose time as another key dimension of human impact. Over time, the eruption evolved from harmless or for some even beneficial spectacle to severe threat, and back to a resource to be exploited. Time plays an important role in the relevance and perception of this hazard, but this 'temporality of risk' plays a yet greater role once we consider that its impact was 
dependent on the specific point in time at which the eruption occurred. Had this eruption occurred in AD 1010 the effects would have been rather different (cf. Dugmore et al. 2007): local farmers (without tractors, plastic seals for fodder, stored clean water, etc.) would likely have been less able to cope with its impact right there and then, but people in the eruption's far-field possessed means of transport somewhat less susceptible to volcanic ash. The effects would have been different again if it had occurred in 11,010 BCE, when Iceland was unoccupied and such a minor eruption would most likely not have been noticed by anybody anywhere. This thought experiment underlines the distinction between a natural event free of human dimensions, and a catastrophe that by definition is the result of the interaction between such an event and human individuals, communities, or societies.

Finally, the materiality of the eruption is worth drawing attention to. Contemporary Icelanders use a wide variety of rugged, heavy-handed engineering and containment measures designed to limit the damage of volcanic eruptions to the immediate environment, and to preserve, for example, crucial infrastructural elements such as bridges. There is sophisticated monitoring equipment as well as specific tools and machines associated with these volcanic landscapes, which although seemingly wild are heavily modified by human intervention. In addition, both state and local communities offer warning and relief measures in the case of volcanic eruptions that provide a safety net for local farmers who themselves employ modern farming and transport technology to, for instance, move livestock out of harm's way swiftly, and to protect themselves, their animals and their supplies against the ash (Figure 3; Bird and Gísladóttir 2012; Bird et al. 2011; Thorvaldsdóttir and Sigbjörnsson 2015). Yet, most catastrophes result in both winners and losers (Scanlon 1988), and shortly after the end of the eruption, the local farming family put into place a custom-built visitors center and gift shop selling not only their own produce, bottled ash from the eruption, but also Eyjafjallajökull-branded clothes, mugs and other paraphernalia (http:/ / www.icelanderupts.is/en); the eruption is connected to and has engendered its own material culture.

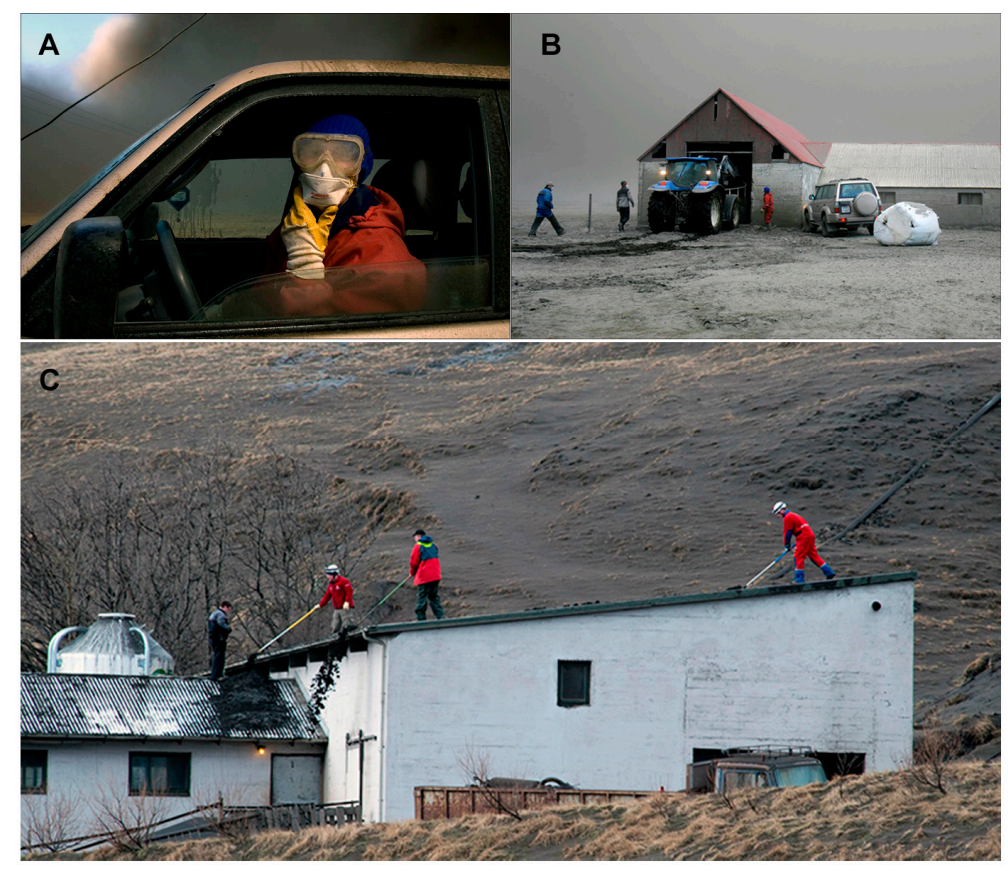

Figure 3. A material culture assortment assisting in coping with the proximal impact of the Eyjafjallajökull eruption: (A) eye and mouth protection, rapid personal transport vehicles (from http:/ / www.16lovers.com/syningar/nigeriusvindlid/islandssvindlid/bref-1-volcanic-eruption/); (B) heavy machinery, plastic seals for fodder, spacious and fairly tight buildings (from http:/ /blogs.sacbee.com/ photos/2010/04/iceland-volcano-part-two.html); (C) running water, safety equipment, electricity (from http:/ / saigonocean.com/trangAlbertDong/Info/InfoSceneVoca.html). 
Volcanic eruptions, albeit usually small in scale, are relatively common occurrences in Iceland and have been since settlement (Thordarson and Larsen 2007). Elsewhere in Europe, these are exceedingly rare events and long since forgotten. The 'disaster gap' between actual experience and traditional ways of coping on the one hand and contemporary attitudes is particularly wide. Current climate change and with it the shifting balance of ice and water on the continental plates may in fact lead to a re-activation of volcanism also in Europe itself-Iceland (Pagli and Sigmundsson 2008; Sigmundsson et al. 2010) and the Eifel Volcanic Field included (Nowell et al. 2006)—lending additional urgency to investigating this particular type of geophysical hazard (McGuire 2013).

\section{Conceptual Framework: Counterfactuals and Scenarios}

Measured on the timescale of a human experience, volcanic eruptions are relatively rare events (even in Iceland) and each eruption differs from others, even when from the same volcanic system. Yet, volcanologists draw on their insights from both recent and ancient volcanism to infer the most likely scenarios for future eruptions (Cashman and Biggs 2014). In history, inferring future societal trends from past events and processes is less common. Yet, David Staley (Staley 2002, p. 72) has provided a provocative program for such a history of the future:

Does history have to be only about the past? "History" refers to both a subject matter and a thought process. That thought process involves raising questions, marshalling evidence, discerning patterns in the evidence, writing narratives, and critiquing the narratives written by others. On methodological grounds, most historians reject as either impractical, quixotic, hubristic, or dangerous any effort to examine the past as a way to make predictions about the future ... However, where at one time thinking about the future did mean making a scientifically-based prediction, futurists today are just as likely to think in terms of scenarios. Where a prediction is a definitive statement about what will be, scenarios are heuristic narratives that explore alternative plausibilities of what might be. With only minimal intellectual adjustment, then, most professionally trained historians possess the necessary skills to write methodologically rigorous "histories of the future".

Staley carefully distinguishes between counterfactual what-if histories that recast past events in alternative ways and using the same methodology to consider events yet to unfold. He argues that the ways in which historians think-their attention to societal dynamics, to contingency and to drawing rigorously on verifiable sources-is patently suited to building strong arguments about future outcomes.

Disaster sociologist Lee Clarke extends this argument to rare events (Clarke 2007, 2008). According to Clarke, a consideration of catastrophic and hence by definition rare events (possibilistic thinking) serves as a way of not merely better understanding social structures (Clarke 2004; García-Acosta 2002), but also for improving general resilience by facilitating virtual stress tests of systems that are impractical or impossible to actually submit to such tests (Clarke 2007, p. 192):

Historians and political scientists have developed an extensive literature on "counterfactuals". Using counterfactual arguments is essential to generalising historical work and, more generally, in reasoning through which historical and political phenomena have been important and which have been trivial (although some historians abjure explicit consideration of counterfactuals) ... My point is that this technical literature on counterfactuals provides rules that can be used to discipline possibilistic thinking.

Another pathway to disciplining counterfactual reasoning is to anchor any scenario strongly in historical evidence, which in the case of environmental histories must come both from the natural and the social sciences. In the climate change adaptation literature (Evans et al. 2013; Rounsevell and Metzger 2010) and in disaster risk reduction (David 2000; Davies et al. 2015), scenario-building and the use of narrative is becoming a key tool for translating findings from the natural sciences into formats 
usable by stakeholders. In volcanology specifically, the construction of eruption scenarios is usually conducted through quantitative probabilistic methods (Neri et al. 2008), where expert assessment is under close scrutiny (Aspinall 2010; Donovan et al. 2012). Useful as they are for thinking though eruptive processes, these scenarios do not or at least rarely consider human responses and impacts. While it may be difficult to provide quantitative estimates of societal disaster responses other than and beyond death tolls and property damage, there is remarkable overlap between the ways of thinking used in volcanological scenario elicitations and Staley's proposal to use historical thinking as a rigorous means of framing future societal trajectories. Add to this Clarke's argument for the importance of rare events, we end with a necessarily interdisciplinary conceptual framework that assists in, as demanded by and Donovan and Clive (2017), 'imagining the unimaginable' in efforts to communicate extreme environmental risks.

One specific tool developed to integrate both natural and human science sources of information in constructing scenarios is labelled Realistic Disaster Scenarios (Mazzorana et al. 2009). Past societal data can feed into the construction of these Realistic Disaster Scenarios (Figure 4). Such an approach could diminish the risk of being surprised by unforeseeable and catastrophic events that, following Taleb (2010), have popularly been termed 'black swans'. A suitably wide temporal angle could turn unforeseeable black swans into foreseeable albeit still difficult to handle 'gray swans' (Stein and Stein 2014, p. 1279) or indeed merely 'gray cygnets' (Rissland 2009, p. 6); chronological largesse enables comparison, which in turn may facilitate learning from the past. In the following, I explore one particular case study of a high-magnitude/low-frequency event (the eruption of the Laacher See volcano), the recurrence of which almost certainly would have catastrophic consequences in a region that is not normally considered at risk from such extreme vents, Europe. Only when extending the chronological window to include prehistoric periods, does it become apparent that Europe, too, may be subject to hazards.

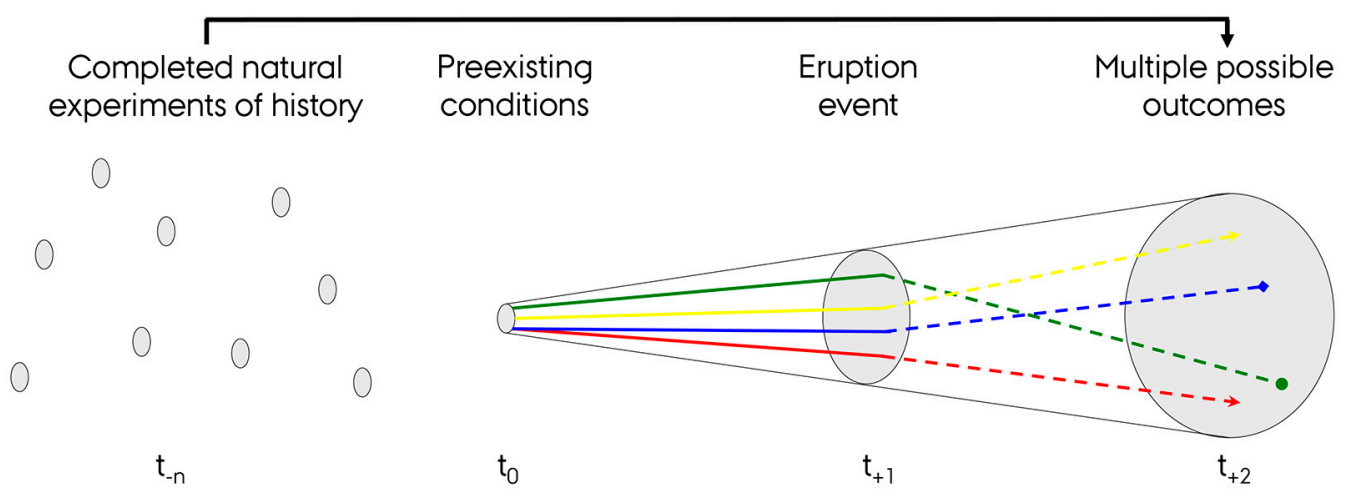

Figure 4. Mazzorana et al.'s (Mazzorana et al. 2009) scenario trumpet extended to include the complete natural experiments of history that (indicated by the arrow) inform the societal aspects of such disaster scenarios. Traditionally, the scenario trumpet begins at $\mathrm{t}_{0}$, our present, and lets a given event unfold over some future time-span, $t_{+1}, t_{+2}, t_{+n}$. In the extended model offered here, evidence for concrete impacts and their mechanisms from numerous past cases at $t_{-n}$ are added to provide a patchwork of relevant evidence that can be harnessed in constructing realistic scenarios, while a specific eventhere the Laacher See eruption 13,000 years ago-serves as a concrete starting point for the scenario at $\mathrm{t}_{0}$.

\section{The Laacher See Case Study}

\subsection{Apocalypse Then}

Approximately 13,000 years ago, the Laacher See volcano located in westernmost part of present-day Germany erupted cataclysmically (Schmincke et al. 1999). Scoring 6 on the so-called Volcanic Explosivity Index (Newhall and Self 1982) and with a calculated magnitude (M) of 6.2 and a peak intensity (I) of 11.7, this highly explosive eruption 
was, in the words of Newhall and Self (Newhall and Self 1982, p. 1232) 'paroxysmal, colossal' and very intense. The physical processes underlying this eruption have been studied in considerable detail and a scenario for the eruption over its weeks-to-months long development has been constructed (Baales et al. 2002; Park and Schmincke 2009; Schmincke 2004; Van den Bogaard and Schmincke 1984, 1985; Van den Bogaard et al. 1990). This includes an ash column that may have been as high as $40 \mathrm{~km}$ at times; the eruption would have been seen, heard and felt across most of Europe (Riede 2017). Furthermore, the nearby River Rhine was temporarily dammed by an accumulation of ejecta, leading to the formation of a lake within the Neuwied Basin as well as substantial upstream damming. This dam broke subsequently and perhaps already whilst the eruption was still on-going, sending one or several river flood waves down the then dried-out downriver areas (Park and Schmincke 1997, 2009). River-rafted material from the eruption is now found as far downstream as the English Channel (Janssens et al. 2012). Volcanic ash (=tephra) from the eruption's different phases was distributed by wind in a south-west to north-east blanket that cuts Europe north of the Alps into two from northern Italy in the south to north-western Russia in the north-east, and from France in the west to Lithuania in the east (Figure 5; Riede et al. 2011). As can be seen from contemporaneous tree rings indicating a period of very poor growth immediately after the eruption, the weather and regional climate were affected negatively (Kaiser 1993). Modelling the climatic impact of the Laacher See eruption (LSE) suggests, however, that these effects were relatively minor and only on an annual and at most decadal timescale (Graf and Timmreck 2001). Table 2 summarizes essential information about the eruption.

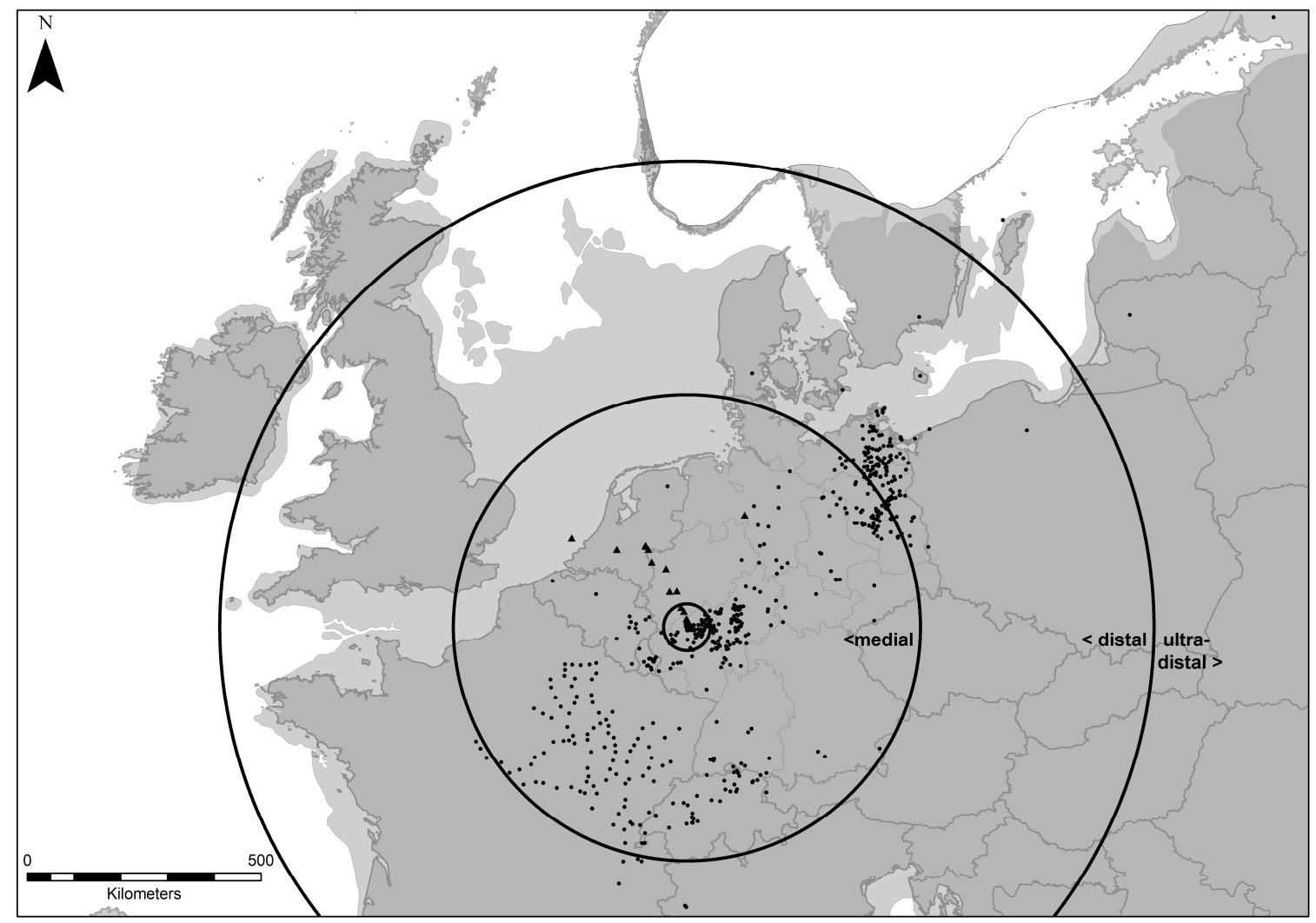

Figure 5. The spatial distribution of occurrences of Laacher See tephra across Europe. 
Table 2. Summary of key characteristics of the Laacher See eruption. BP = before present (1950); $\mathrm{cal} \mathrm{BP}=$ calibrated years before present, i.e., the measured radiocarbon age has been converted (calibrated) to calendar age.

\begin{tabular}{|c|c|c|}
\hline Characteristic & Description & References \\
\hline \multirow{5}{*}{$\begin{array}{l}\text { Best estimated dates based on } \\
\text { various approaches }\end{array}$} & 12,916 cal BP & Baales et al. (2002) \\
\hline & $12,900 \pm 560\left(\mathrm{Ar}^{40} / \mathrm{Ar}^{39}\right) \mathrm{BP}$ & Van den Bogaard (1995) \\
\hline & 12,880 varve years $B P$ & Brauer et al. (1999) \\
\hline & $12,980-12,890 \mathrm{cal} \mathrm{BP}$ & Bronk Ramsey et al. (2015) \\
\hline & $13,034 \mathrm{cal} \mathrm{BP}$ & Van Raden et al. (2013) \\
\hline $\begin{array}{l}\text { Correlated geophysical, cosmogenic, } \\
\text { and climatic events }\end{array}$ & $\begin{array}{l}\text { 'acid rain, increased rain fall, } \\
\text { reduction of solar radiation and drop } \\
\text { of temperature' }\end{array}$ & $\begin{array}{l}\text { Schmincke (2006, p. 152), Graf and } \\
\text { Timmreck (2001) }\end{array}$ \\
\hline Fallout directions & $\mathrm{NE}>\mathrm{SSW}$ & Van den Bogaard and Schmincke (1984) \\
\hline Maximum height of Plinian column & $<40 \mathrm{~km}$ & Van den Bogaard and Schmincke (1985) \\
\hline Minimum height of Plinian column & $>20 \mathrm{~km}$ & Schmincke et al. (1999) \\
\hline Volume of extruded magma & $\begin{array}{l}\geq 20 \mathrm{~km}^{3} \text { loose ejecta } \approx 6.3 \mathrm{~km}^{3} \text { dense } \\
\text { rock equivalent }\end{array}$ & Schmincke et al. (1999) \\
\hline Estimated discharge rate & $3-5 \times 10^{8} \mathrm{~kg} / \mathrm{s}$ & Schmincke (2006) \\
\hline Eruptive temperature & $\begin{array}{l}250^{\circ} \mathrm{C} \text { (pyroclastic flows); } 8800^{\circ} \mathrm{C} \\
\text { (magma) }\end{array}$ & Schmincke (2006) \\
\hline Sulfur injected into the atmosphere & $1.9-15 \times 10^{12} \mathrm{~g}$ & Schmincke et al. (1999) \\
\hline $\begin{array}{l}\text { Sulfate signal in Greenland ice } \\
\text { core NGRIP }\end{array}$ & Not detected & Abbott and Davies (2012) \\
\hline Area covered by pyroclastic currents & $>1400 \mathrm{~km}^{2}$ & Van den Bogaard and Schmincke (1984) \\
\hline Area affected by ash fallout & $>315,000 \mathrm{~km}^{2}$ & $\begin{array}{l}\text { Fisher and Schmincke (1984), } \\
\text { Riede et al. (2011) }\end{array}$ \\
\hline Cooling induced & $1-2^{\circ} \mathrm{C}$ & Graf and Timmreck (2001) \\
\hline $\begin{array}{l}\text { High-latitude }\left(>60^{\circ} \mathrm{N}\right) \text { amplifying } \\
\text { factor for cooling }\end{array}$ & +4 (late winter) $/-4$ (late summer) ${ }^{\circ} \mathrm{K}$ & Graf and Timmreck (2001) \\
\hline Regional abandonment & $\begin{array}{l}\text { Affected part of the North European } \\
\text { Plain }\end{array}$ & $\begin{array}{l}\text { Riede (2007); Riede (2008); } \\
\text { Riede (2012, 2016) }\end{array}$ \\
\hline Volcanic Explosivity Index (VEI) & 6 & Newhall and Self (1982) \\
\hline Magnitude (M) & 6.2 & Mason et al. (2004) \\
\hline Intensity (I) & $11.5-11.7$ & Pyle (2000) \\
\hline Destructiveness (D) & $\geq 3.1$ & Pyle (2000) \\
\hline
\end{tabular}

Adding to the volcanological research, recent archaeological work has also highlighted that contemporaneous communities of Stone Age hunter-gatherers were affected by the eruption (Riede 2008, 2015, 2017). The massive deposition of volcanic ejecta in the area surrounding the volcano sealed that landscape including plentiful plant remains (Baales et al. 1999; Street 1986) and animal tracks (Baales and von Berg 1997; Von Berg 1994b), as well as archaeological sites that range from very small (Von Berg 1994a) to extensive (Baales 2002, 2006). The volcano's near field appears to have been depopulated for decades until re-colonization slowly commenced from the west (Baales and Jöris 2002). The eruption and its attendant tephra fallout also had societal effects in the far field that were at the same time subtler (no depopulation) and more pronounced (evident changes in the cultural repertoire) than those in the near field. The fallout likely affected ecosystem functioning through negative impacts on animal and human respiratory health (Riede and Bazely 2009) and by increasing dental wear (Riede and Wheeler 2009). It is likely that these ash-induced effects interacted with the eruption's effects on weather and climate (inherently turbulent at this time (Lowe et al. 2008)) to also disrupted traditional travel and communication routes, leading to a breakdown of the social networks that bound these communities, already stressed by on-going climate change, together (Riede 2014b). In interaction with ecological and societal factors, the eruption led to the abandonment of affected regions towards 
the northeast of the volcano (Riede 2016); these swaths of land were unattractive or even dangerous for up to several decades after the eruption and, in analogy with the ways in which many traditional societies elsewhere handled such hazards (Lowe et al. 2002; Oetelaar 2015), may have been declared off-limits, taboo. In turn, this resulted in the isolation of communities along the margins of the tephra fallout in southern Scandinavia. This isolation then led to culture change that is reflected in the stone tool repertoire of the period immediately following the eruption (Riede 2014b, 2015). Dramatically, these changes can be taken to signal the loss of important technologies such as the bow and arrow (Riede 2009). Yet, it is also possible that the eruption event did represent a not entirely unwelcome opportunity to instigate social change. Living conditions in southern Scandinavia (the refuge area not directly impacted by the Laacher See ashfall) in the post-eruption period were favorable, resources fairly abundant. Perhaps some communities seized the opportunity to effect positive societal changes in a form of splendid isolation (Riede 2017).

\subsection{Apocalypse Now?}

Conjoining the volcanological and archaeological evidence for the Laacher See eruption and its human impacts, it is possible to highlight a series of potential implications of renewed eruptive activity. Such a low frequency/high magnitude mid-continent eruption in Europe lasting several weeks or months would affect a very large number of people both in the near- and as well as the far-field (Figure 6). In addition, it would likely lead to a prolonged closure of European or even Eurasian airspace, an at least temporary collapse of air- and water-based supply chains providing many daily consumables, and key power supply nodes would be at risk (Figure 7). Infrastructure impacts (Wilson et al. 2015) as well as impacts on agriculture (Arnalds 2013) would be significant. The economic implications of these immediate effects and their longer-term clean-up and repair efforts are staggering (Hayes et al. 2015; Wilson et al. 2015), and would likely put European economic as well as political systems under considerable strain. Leder and colleagues (Leder et al. 2017) have recently estimated (using conservative eruption parameters) a directly affected population of six million and a loss of capital stock due to building damage alone of around 20-27 billion EUR. However, other costs would certainly ensue, owing to the need to clean-up (cf. Hayes et al. 2015), due to increased physical and mental health care demands (cf. Adams and Adams 1984), and impacts on river- and airborne logistics chains. The River Rhine is an important economic highway in Europe and any effects on it would also directly affect all countries along it up- as well as downstream (Uehlinger et al. 2009). Assuming ash fall not unlike that 13,000 years ago, at least 14 contemporary countries would be directly affected, raising the additional challenge of cross-border coordination and mitigation (Donovan and Oppenheimer 2012, 2017).

In similar scenario-building exercises that consider a Laki-like eruption and its impact on European countries (Schmidt et al. 2011; Sonnek et al. 2017), the health care burden is flagged up as significant. Laki-style events, so-called fissure eruptions, are different from the much more explosive and violent Laacher See-style eruptions in that they are not nearly as destructive in a direct physical manner, but often last long and eject stupendous amounts of poisonous gases such as sulfur. Sulfur in turn can cause dry fogs (often at great distances from the eruptive center) with attendant impacts on ecosystems and in particular respiratory health (Grattan et al. 2003; Grattan and Charman 1994). However, the human effects of volcanic eruptions often go beyond dry fogs and climate impacts. From other eruptions, it is known that also mental health is affected (Adams and Adams 1984). Following an LSE-style eruption, significant land areas would become unattractive for settlement and economic exploitation for some time, leading to domestic or even cross-border migration. With such challenges looming, political, but also religious changes (including radicalization) are not unlikely, as were demonstrably the results of such eruptions in the past and must be taken seriously as candidate effects of future eruptions (cf. Chester 2005). Indeed, the indirect impacts on European society of even very remote eruptions have been considerable (Krämer 2009; Luterbacher and Pfister 2015). 


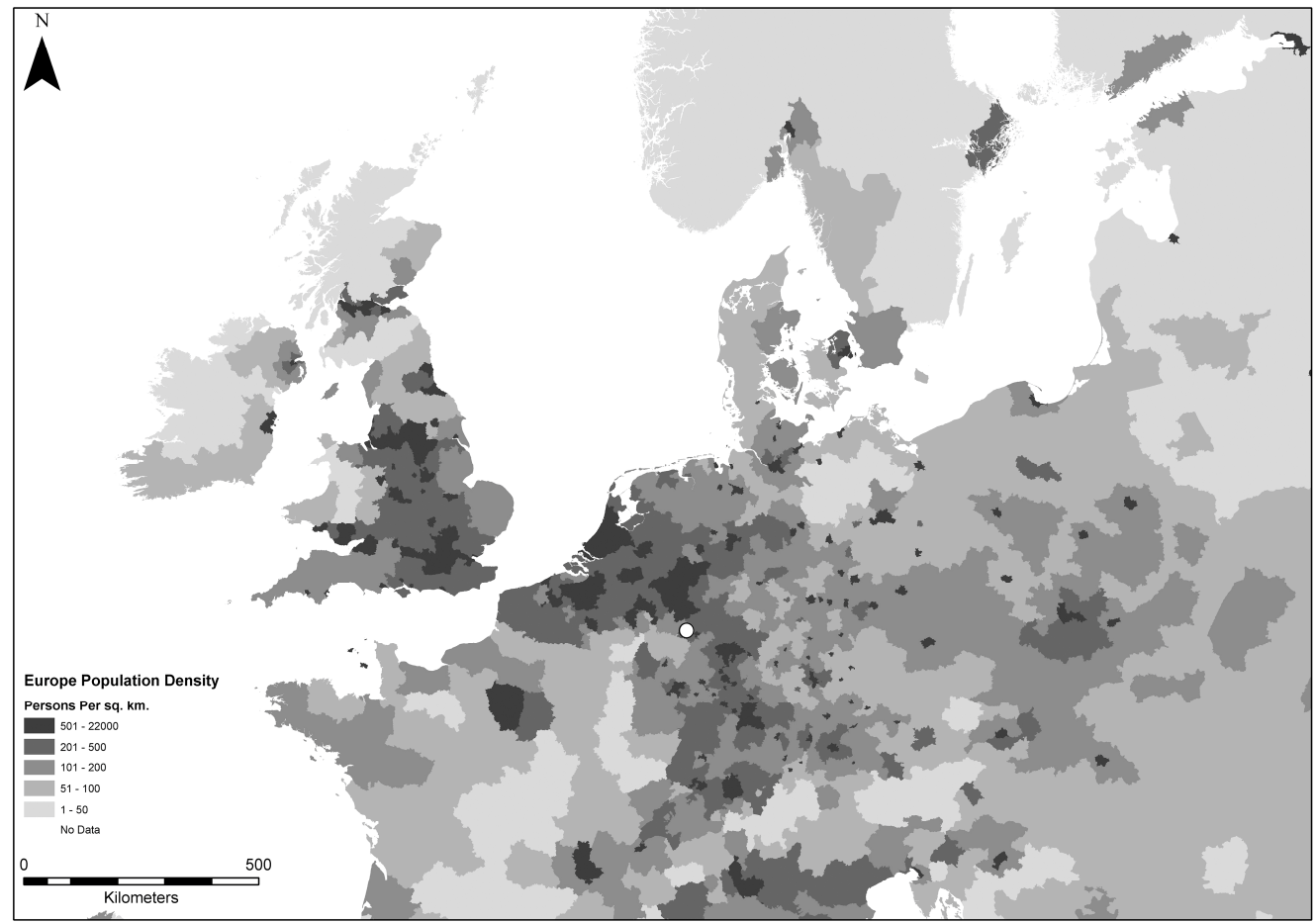

Figure 6. Current population densities in Europe with the Laacher See volcano marked in the region's center. Compare this to Figure 5 above. Source: ESRI.

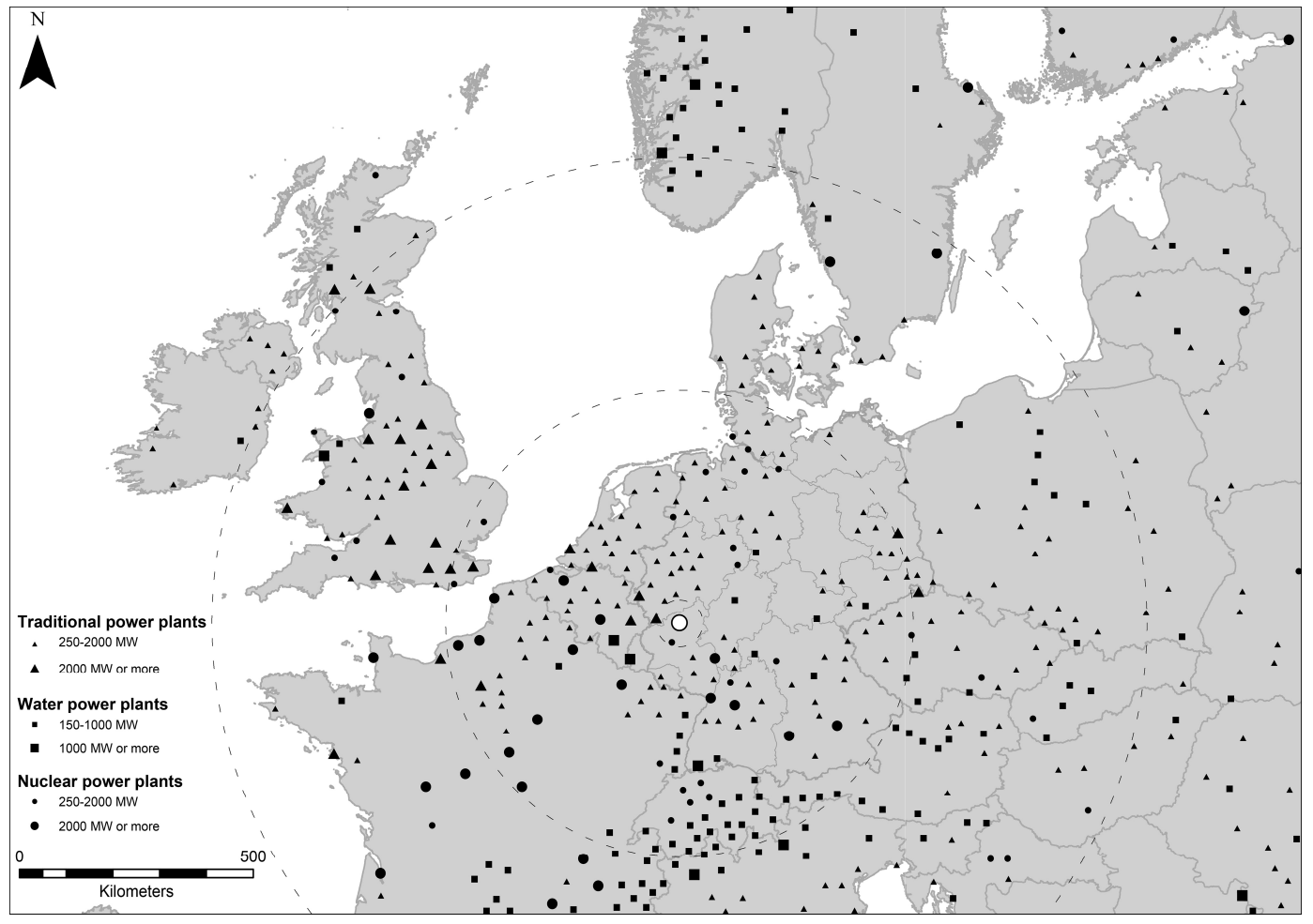

Figure 7. The location of power plants in Europe and the currently known distribution of Laacher See fallout. Stippled lines mark the proximal ( $<50 \mathrm{~km}$, medial $(50-500 \mathrm{~km})$, distal (500-1000 km) and ultra-distal $(>1000 \mathrm{~km})$ ) hazard zones, as in Figure 5. Redrawn from http://maps.unomaha.edu/peterson. 
Thinking historically about the future, Oreskes and Conway (Oreskes and Conway 2014) offer a dark vision for Europe's future. Existing political and economic instability, climate change pressures and the wider geopolitical landscape might make the handling of event such as a major volcanic eruption in the heart of Europe challenging. In drawing on the societal effects documented in historic eruptions and the Laacher See event itself, it is easy and tempting to paint worst case scenarios for renewed volcanic activity in the Eifel Volcanic Field. The Realistic Disaster Scenario methodology, however, constrains such speculation by providing a methodology for developing scenarios such as the one sketched out above, all depending on the intended planning effort. Based on such scenarios, the surge capacities of existing infrastructure and social structures can be considered (Clarke 2008; Michel-Kerjan 2012). In addition, carefully thinking through the impacts of such an extreme event on European societies may also stimulate a consideration of the event as a window of opportunity for positive societal change (Birkmann et al. 2010; Olshansky et al. 2012; Solnit 2010), just as it may have been for communities 13,000 years ago. Either way, anchoring such scenarios in an event that actually has occurred provides specificity and an evidence-base from which to work.

\section{Discussion}

Archaeologists and the public alike have been fascinated by past calamities since at least the discovery of Pompeii. Yet, this fascination is rarely coupled with adequate notions of how such extreme events and the transformation into disasters through their interaction with contemporaneous social structures may contribute to the patterns and processes of history unfolding. The growing body of case studies concerned with the intricate effect pathways from eruption to social change underlines that calamities such as volcanic eruptions can lead to cascading effects that reverberate through social and demographic networks at variable speeds. Placed in broader comparative perspective, it seems that such events can have long-term social and political legacies, and their effects are often indirect, mediated by culturally specific components such as religion, and that these effects can occur or indeed be amplified at great distances from the actual calamity (Cashman and Giordano 2008; Grattan et al. 2007; Grattan 2006; Torrence and Grattan 2002). The communities affected by the Laacher See eruption were very different from contemporary ones. Yet, similar examples of the long reach of sometimes very distant volcanic eruptions can be found from, for instance, the Medieval period when economies and politics were much closer to those of the present (Buntgen et al. 2016; Huhtamaa and Helama 2017; McCormick et al. 2007; Price and Gräslund 2015; Toohey et al. 2016). Certainly, issues of data resolution often plague the study of past disasters, but these limitations are arguably counterbalanced by privileged access to unique long-term information on societies and their material expressions of livelihood, as well as a similarly long-term perspective on the critical magnitude/frequency relationship of the relevant natural hazards, by the opportunity to carefully select case studies, and by the number of data-points offered by the archaeological record.

I have argued here that information from past calamities may be used to inform planning for future extreme events. Indeed, the stakes are high, given their potentially destructive and disruptive impacts. Such 'possibilism' carries with it the danger of hysteria, but archaeological and historical data can be effectively used to modulate these by offering historically informed, evidence-based information on both the geophysical as well as sociocultural parameters of past extreme events that, critically, retains a great deal of immediacy and intimacy.

The current discourse about climate change and the impacts of extreme events is strongly catastrophic and apocalyptic in its rhetoric (see Dawdy 2009; Dörries 2010; Hulme 2008; Mauelshagen 2009; Nielsen 2013), and it is strongly focused on global 'future narratives' rather than narratives that are centered on particular locales or regions and their histories. With a heavy technocratic and natural scientific focus the otherwise important milestone publications of, for instance, the Intergovernmental Panel on Climate Change (IPCC; see, for instance, Field et al. 2012; Smith et al. 2009), are arguably distant and abstract for many. Ironically, as Van de Noort (2011) has noted, the IPCC draws heavily on paleoclimatic data as a foundation for its prediction 
of future climate change, but does not draw to any meaningful degree on corresponding 'paleosocietal' —archaeological, historical—data when it comes to addressing future societal change. Studies of past volcanism are plagued by a very similar dilemma: A suite of excellent databases of past volcanic activity as well as of other paleo-hazards (e.g., www.ngdc.noaa.gov/hazard/tsu_db.shtml) exist, some of which are expressly constructed to aid in risk reduction research (Bryson et al. 2006; Crosweller et al. 2012; Siebert et al. 2010). Yet, none of these databases contain any or none other than trivial information on the societies actually affected by these eruptions. Whilst fully appreciating their utility in studies of past geological processes (e.g., Deligne et al. 2010) and whilst also fully appreciating the large amounts of labor that have gone into assembling these databases in the first place, they do not contribute to the investigation past human vulnerability, resilience or responses in a historically specific and historically informed manner.

The archaeological debate on collapse aside (see Middleton 2012, 2013; Tainter 2008), the fact that current climate change is perceived and talked about as catastrophic alone warrants a focus on catastrophic climatic change, and extreme events in the past also. Hulme (2008, p. 5) has noted that

We are living in a climate of fear about our future climate. The language of the public discourse around global warming routinely uses a repertoire which includes words such as 'catastrophe', 'terror', 'danger', 'extinction' and 'collapse'. To help make sense of this phenomenon the story of the complex relationships between climates and cultures in different times and in different places is in urgent need of telling. If we can understand from the past something of this complex interweaving of our ideas of climate with their physical and cultural settings we may be better placed to prepare for different configurations of this relationship in the future.

Better understanding these past configurations could inform current debate. In the geosciences, there is increasing recognition that discussions of the threat posed by climate change and by extreme geophysical events are driven not such my information but by values. The vulnerability of contemporary Europe, for instance, to extreme events such as a major volcanic eruption are therefore not 'matters of fact' but 'matters of concerns' (Stewart and Lewis 2017). What archaeology can add is immediacy and intimacy to specific volcanic hazard forecast scenarios (e.g., Mastrolorenzo et al. 2006; Schmidt et al. 2011; Sonnek et al. 2017) by focusing on both the vulnerability and the resilience of past communities. People relate readily to the past of the places they live, and indeed draw much of their identity from historical and archaeological narratives (Sommer 2000). Adding this human dimension is hence likely to assist in framing such hazards not only in terms of facts but also in terms of concerns.

Archaeology cannot, except in very rare circumstances (e.g., Cooper and Sheets 2012; Guttmann-Bond 2010), provide concise blueprints for designing sustainable adaptations to volcanic hazards or other, climate-induced challenges. Rather, archaeology can, in the form of 'climate change archaeology', contribute more broadly to a balanced understanding of the relationship between humans and the environment; archaeology can tell—on occasion using the narrative devices of catastrophe and apocalypse-stories of past successful and unsuccessful adaptive pathways; and archaeology can, through its established communication channels (i.e., museums, school curricula, etc.) contribute to environmental literacy and thus to increased resilience (Dix and Röhrs 2007; Van de Noort 2013). It is worth noting in this connection that museums of culture history generally and in most European countries at least attract larger number of visitors than their natural history counterparts (see http://www.egmus.eu/). Encouragingly, several recent exhibitions have taken up the themes of catastrophe and disaster from a cultural perspective (Blæsild and Beck 2016; Höfchen et al. 2014; Pyle 2017; Schenk et al. 2014), although the Laacher See eruption and its impact on the culture history of Europe remains little utilized. Instead, this eruption is used in the context of geological outreach and tourism only (Bitschene and Schüller 2011; Erfurt-Cooper 2010). Yet, museums of culture history could offer, I argue, high-profile platforms for outreach, for education, and for debate around the role of climate and environmental change and extreme events in social change: past, present and future. 


\section{Conclusions}

The denial of catastrophic risks and the potential impact of extreme events and their disastrous societal consequences may come at a high cost (e.g., Kieffer 2013; Plag 2014); complacency will only aggravate the next disaster (Sparks 2007). Modern societies are, due to the inherent potential destructiveness of such events and the entanglement of modern societies in and dependence on expansive networks, patently not immune to such events (Donovan and Oppenheimer 2013, 2017; Plag 2014). It has been argued that existentialist questions posed by the threat of natural hazards ought not to be avoided in either scientific or public discourse (Rees 2013), although it is paramount that a balance between hysterical catastrophism and myopic naiveté is struck.

There is no reason why the information on past disasters and on past vulnerability that can be wrought from the archaeological record should not be used more proactively as part of an educational strategy intended to raise resilience and to allow communities to live sustainably with, for instance, volcanic risks. It is precisely the periods of repose, in which such educational initiatives should set in (Sparks 2007). This emerging focus on the role of culture (Mercer et al. 2012) and on sustainable livelihoods (Kelman and Mather 2008) in disaster risk reduction offers a fertile meeting ground precisely because the past feeds into processes of identity creation and, in the form of (geo-)cultural heritage, furnishes a resource for livelihood and action. In this way, the rich data provided by these elements of cultural heritage—our 'usable past' (Stump 2013, p. 268)—could play a more proactive role in present and future risk reduction strategies and in the strengthening of social resilience that emerges out of a coupling between traditional and scientific knowledge and methods, just as disasters emerge at the violent interface between geological and societal forces.

Currently, the occurrence of a high-magnitude volcanic eruption from the Laacher See edifice, right in the heart of Europe, is only entertained in film (Janson 2009), in fiction (Schreiber 2006) and in the tabloid press (see, for example, http:/ /www.bild.de/news/2007/news/forscher-ausbruchdeutschland-1399914.bild.html and the discussion in http:/ /www.wired.com/wiredscience/2012/01/ fearmongering-gets-started-in-2012-laacher-see-is-not-ready-to-blow/); indeed it is film-makers and writers of fiction that excel at drafting scenarios of future calamities (Atwood 2011; Horn 2012, 2014). However, equipped with thinking the future through historically, with possibilistic reasoning and with the vast evidence base of the archaeological and historical records, environmental deep historians and archaeologists are now well-positioned to 'past-forward' this evidence and also provide powerful and useful narratives and scenarios for the future. The scenarios that can be built using the evidential building blocks of the Laacher See case study itself and supplemented with evidence of societal impacts related to past eruptions should have a relevance beyond the possibility of renewed volcanic activity in the Eifel Volcanic Field. The Laacher See eruption merely serves as an exemplar of an extreme event with far-reaching consequences. The resilience and governance required to respond to such an event would also come into play more generically in relation to other calamities.

Many disciplines across the human and natural sciences have interests in prognoses of future societal developments (cf. Mathews and Barnes 2016). The natural sciences draw on paleoclimatic data and draft scenarios strongly focused on these parameters, whilst the development of scenarios that explore in greater depths the social dimensions of future climate change fall under the purview of those producing literary fiction (Johns-Putra 2016; Nikoleris et al. 2017). The narration of past human-climate-environment interactions and their societal consequences (constrained both by paleoclimate data, as well as the evidence from the archaeological and historical records) offers a third pathway to imagining such futures. The past here serves as an analytical mirror with opportunities for demonstrating the complex causal relationships between climate change, environmental change, individual and collective actions and their consequences. Such narratives can be presented not just through scientific writings, but through the well-established outreach avenues available to archaeologists and historians: museums of culture history. By locating the question of human impacts of environmental change and events within the domain of culture history, it can be made clear that the problems generated by these, and their potential solutions, also lie (at least partly) within that sphere. 
Acknowledgments: This work has been funded by the Danish Council for Independent Research Sapere Aude Grant 6107-00059B (Apocalypse then? The Laacher See volcanic eruption (13,000 years before present), Deep Environmental History and Europe's geo-cultural heritage). The ideas presented here benefited from the responses to related presentations at the panel on Climate Change and the Future: Exploring the 'Social Time' of Transformation through Scenario-based Practice at the Royal Anthropological Institute's Anthropology, Weather \& Climate Change conference in May 2016 and the subsequent Humanities for the Environment gathering in Sigtuna in September 2016. I thank Steven Hartman for the invitation to that meeting and Poul Holm and Ruth Brennan for the invitation to contribute to this special issue. Parts of this paper are based on a book-length treatment of the Laacher See eruption and its societal impacts (see http://en.unipress.dk/udgivelser/s/ \unhbox voidb@x \hbox\{splendid-isolation/\}).

Conflicts of Interest: The author declares no conflict of interest. The founding sponsors had no role in the design of the study; in the collection, analyses or interpretation of data; in the writing of the manuscript; nor in the decision to publish the results.

\section{References}

Abbott, Peter M., and Siwan M. Davies. 2012. Volcanism and the Greenland Ice-Cores: The Tephra Record. Earth-Science Reviews 115: 173-91. [CrossRef]

Adams, Paul R., and Gerald R. Adams. 1984. Mount Saint Helens's Ashfall: Evidence for a Disaster Stress Reaction. American Pychologist 39: 252-60. [CrossRef]

Adger, W. Neil. 2000. Social and Ecological Resilience: Are They Related? Progress in Human Geography 24: 347-64. [CrossRef]

Adger, W. Neil. 2006. Vulnerability. Global Environmental Change 16: 268-81. [CrossRef]

Albarella, Umberto, ed. 2001. Environmental Archaeology: Meaning and Purpose. Environmental Science and Technology Library. London: Kluwer Academic Publishers, vol. 17.

Alexander, David E. 1995. A Survey of the Field of Natural Hazards and Disaster Studies. In Geographical Information Systems in Assessing Natural Hazards. Edited by Alberto Carrara and Fausto Guzetti. Amsterdam: Kluwer Academic, pp. 1-19.

Alexander, David E. 1997. The Study of Natural Disasters, 1977-1997: Some Reflection on a Changing Field of Knowledge. Disasters 21: 284-304. [CrossRef] [PubMed]

Alexander, David E. 2013. Volcanic Ash in the Atmosphere and Risks for Civil Aviation: A Study in European Crisis Management. International Journal of Disaster Risk Science 4: 9-19. [CrossRef]

Arnalds, Olafur. 2013. The Influence of Volcanic Tephra (Ash) on Ecosystems. In Advances in Agronomy. Edited by Donald L. Sparks. Cambridge: Academic Press, pp. 331-80.

Aspinall, Willy. 2010. A Route to More Tractable Expert Advice. Nature 463: 294-95. [CrossRef] [PubMed]

Atwood, Margaret. 2011. In Other Worlds: Science Fiction and the Human Imagination. London: Virago.

Baales, Michael. 2002. Vulkanismus Und Archäologie Des Eiszeitalters Am Mittelrhein. Die Forschungsergebnisse Der Letzten Dreissig Jahre. Jahrbuch des Römisch-Germanischen Zentralmuseums Mainz 49: 43-80.

Baales, Michael. 2006. Final Palaeolithic Environment and Archaeology in the Central Rhineland (Rhineland-Palatinate, Western Germany): Conclusions of the Last 15 Years of Research. Anthropologie 110: 418-44. [CrossRef]

Baales, Michael, and Olaf Jöris. 2002. Between North and South-A Site with Backed Points from the Final Allerod: Bad Breisig, Kr. Ahrweiler (Central Rhineland, Germany). L'Anthropologie 106: 249-67. [CrossRef]

Baales, Michael, and Axel von Berg. 1997. Tierfährten in Der Allerödzeitlichen Vulkanasche Des Laacher See-Vulkans Bei Mertloch, Kreis Mayen-Koblenz. Archäologisches Korrespondenzblatt 27: 1-12.

Baales, Michael, Felix Bittmann, and Bernd Kromer. 1999. Verkohlte Bäume Im Trass Der Laacher See-Tephra Bei Kruft (Neuwieder Becken). Ein Beitrag Zur Datierung Des Laacher See-Ereignisses Und Zur Vegetation Der Alleröd-Zeit Am Mittelrhein. Archäologisches Korrespondenzblatt 28: 191-204.

Baales, Michael, Olaf Jöris, Martin Street, Felix Bittmann, Bernhard Weninger, and Julian Wiethold. 2002. Impact of the Late Glacial Eruption of the Laacher See Volcano, Central Rhineland, Germany. Quaternary Research 58: 273-88. [CrossRef]

Bankoff, Gregory. 2003. Vulnerability as a Measure of Change in Society. International Journal of Mass Emergencies and Disasters 21: 5-30. 
Bankoff, Greg. 2009. Cultures of Disaster, Cultures of Coping: Hazard as a Frequent Life Experience in the Philippines, 1600-2000. In Natural Disasters, Cultural Responses: Case Studies toward a Global Environmental History. Edited by Christof Mauch and Christian Pfister. Lanham: Lexington Books, pp. 265-84.

Barclay, Jenni, Kat Haynes, Bruce F. Houghton, and David Johnston. 2015. Social Processes and Volcanic Risk Reduction. In Encyclopedia of Volcanoes. Edited by Haraldur Sigurdsson, Bruce F. Houghton, Hazel Rymer, John Stix and Steve R. McNutt. San Diego: Academic Press, pp. 1203-14.

Benediktsson, Karl, Katrin Anna Lund, and Edward Huijbens. 2011. Inspired by Eruptions? Eyjafjallajökull and Icelandic Tourism. Mobilities 6: 77-84. [CrossRef]

Bird, Deanne K., and Guðrún Gísladóttir. 2012. Residents' Attitudes and Behaviour before and after the 2010 Eyjafjallajökull Eruptions-A Case Study from Southern Iceland. Bulletin of Volcanology 74: 1263-79. [CrossRef]

Bird, Deanne K., Guðrún Gísladóttir, and Dale Dominey-Howes. 2011. Different Communities, Different Perspectives: Issues Affecting Residents' Response to a Volcanic Eruption in Southern Iceland. Bulletin of Volcanology 73: 1209-27. [CrossRef]

Birkmann, Jörn. 2006a. Measuring Vulnerability to Promote Disaster-Resilient Societies: Conceptual Frameworks and Definitions. In Measuring Vulnerability to Natural Hazards: Towards Disaster Resilient Societies. Edited by Jörn Birkmann. New York: United Nations University, pp. 9-54.

Birkmann, Jörn, ed. 2006b. Measuring Vulnerability to Natural Hazards: Towards Disaster Resilient Societies. New York: United Nations University.

Birkmann, Jörn, Philip Buckle, Jill Jaeger, Mark Pelling, Neysa J. Setiadi, Matthias Garschagen, Neil Fernando, and Jürgen Kropp. 2010. Extreme Events and Disasters: A Window of Opportunity for Change? Analysis of Organizational, Institutional and Political Changes, Formal and Informal Responses after Mega-Disasters. Natural Hazards 55: 637-55. [CrossRef]

Bitschene, Peter, and Andreas Schüller. 2011. Geo-Education and Geopark Implementation in the Vulkaneifel European Geopark. GSA Field Guide 22: 29-34.

Blæsild, Marie, and Line Beck. 2016. 'Mild Apokalypse' På Moesgaard Museum. Jordens Folk 51: 6-13.

Brauer, Achim, Christoph Endres, and Jörg F. W. Negendank. 1999. Lateglacial Calendar Year Chronology Based on Annually Laminated Sediments from Lake Meerfelder Maar, Germany. Quaternary International 61: 17-25. [CrossRef]

Bronk Ramsey, Christopher, Paul G. Albert, Simon P. E. Blockley, Mark Hardiman, Rupert A. Housley, Christine S. Lane, Sharen Lee, Ian P. Matthews, Victoria C. Smith, and John J. Lowe. 2015. Improved Age Estimates for Key Late Quaternary European Tephra Horizons in the Reset Lattice. Quaternary Science Reviews 118: 18-32. [CrossRef]

Bryson, Robert U., Reid A. Bryson, and Anthony Ruter. 2006. A Calibrated Radiocarbon Database of Late Quaternary Volcanic Eruptions. eEarth Discussions 1: 123-34. [CrossRef]

Budd, Lucy, Steven Griggs, David Howarth, and Stephen Ison. 2011. A Fiasco of Volcanic Proportions? Eyjafjallajökull and the Closure of European Airspace. Mobilities 6: 31-40. [CrossRef]

Buntgen, Ulf, Vladimir S. Myglan, Fredrik Charpentier Ljungqvist, Michael McCormick, Nicola Di Cosmo, Michael Sigl, Johann Jungclaus, Sebastian Wagner, Paul J. Krusic, Jan Esper, and et al. 2016. Cooling and Societal Change During the Late Antique Little Ice Age from 536 to around 660 Ad. Nature Geoscience 9: 231-36. [CrossRef]

Cameron, Fiona, and Brett Neilson, eds. 2015. Climate Change and Museum Futures. Routledge Research in Museum Studies. London: Routledge.

Cameron, Fiona, Bob Hodge, and Juan Francisco Salazar. 2013. Representing Climate Change in Museum Space and Places. Wiley Interdisciplinary Reviews: Climate Change 4: 9-21. [CrossRef]

Carson, Rob. 2000. Mount St. Helens: The Eruption and Recovery of a Volcano. Seattle: Sasquatch Books.

Carter, Adam, and Christel van Eck. 2014. Science \& Stories. Bringing the Ipcc to Life. Oxford: Climate Outreach Information Network.

Caseldine, Chris, and Chris S. M. Turney. 2010. The Bigger Picture: Towards Integrating Palaeoclimate and Environmental Data with a History of Societal Change. Journal of Quaternary Science 25: 88-93. [CrossRef]

Cashman, Katharine, and Juliet Biggs. 2014. Common Processes at Unique Volcanoes-A Volcanological Conundrum. Frontiers in Earth Science 2. [CrossRef] 
Cashman, Katharine V., and Giudo Giordano. 2008. Volcanoes and Human History. Journal of Volcanology and Geothermal Research 176: 325-29. [CrossRef]

Chakrabarty, Dipesh. 2009. The Climate of History: Four Theses. Critical Inquiry 35: 197-222. [CrossRef]

Chakrabarty, Dipesh. 2014. Climate and Capital: On Conjoined Histories. Critical Enquiry 41: 1-23. [CrossRef]

Chester, David K. 2005. Theology and Disaster Studies: The Need for Dialogue. Journal of Volcanology and Geothermal Research 146: 319-28. [CrossRef]

Chester, David K., Martin Degg, Angus M. Duncan, and John E. Guest. 2001. The Increasing Exposure of Cities to the Effects of Volcanic Eruptions: A Global Survey. Environmental Hazards 2: 89-103.

Clarke, Lee. 2004. Using Disaster to See Society. Contemporary Sociology 33: 137-39. [CrossRef]

Clarke, Lee. 2007. Thinking Possibilistically in a Probabilistic World. Significance 4: 190-92. [CrossRef]

Clarke, Lee. 2008. Possibilistic Thinking: A New Conceptual Tool for Thinking About Extreme Events. Social Research 75: 669-90.

Cooper, Jago, and Payson D. Sheets, eds. 2012. Surviving Sudden Environmental Change. Boulder: University of Colorado Press.

Crosweller, Helen Sian, Baneet Arora, Sarah Krystyna Brown, Elizabeth Cottrell, Natalia Irma Deligne, Natalie Ortiz Guerrero, Laura Hobbs, Koji Kiyosugi, Susan Clare Loughlin, Jonathan Lowndes, and et al. 2012. Global Database on Large Magnitude Explosive Volcanic Eruptions (Lameve). Journal of Applied Volcanology 1: 4. [CrossRef]

Crutzen, Paul J., and Eugene F. Stoermer. 2000. The Anthropocene. Global Change Newsletter 41: 17-18.

Cutter, Susan L. 1996. Vulnerability to Environmental Hazards. Progress in Human Geography 20: 529-39. [CrossRef]

Cutter, Susan L., Bryan J. Boruff, and W. Lynn Shirley. 2003. Social Vulnerability to Environmental Hazards. Social Science Quarterly 84: 242-61. [CrossRef]

David, Alexander. 2000. Scenario Methodology for Teaching Principles of Emergency Management. Disaster Prevention and Management: An International Journal 9: 89-97.

Davies, Siwan M., Gudrun Larsen, Stefan Wastegård, Chris S. M. Turney, Valerie A. Hall, Lisa Coyle, and Thor Thordarson. 2010. Widespread Dispersal of Icelandic Tephra: How Does the Eyjafjöll Eruption of 2010 Compare to Past Icelandic Events? Journal of Quaternary Science 25: 605-11. [CrossRef]

Davies, Tim, Sarah Beaven, David Conradson, Alex Densmore, J. C.Gaillard, David Johnston, Dave Milledge, Katie Oven, Dave Petley, Jonathan Rigg, and et al. 2015. Towards Disaster Resilience: A Scenario-Based Approach to Co-Producing and Integrating Hazard and Risk Knowledge. International Journal of Disaster Risk Reduction 13: 242-47. [CrossRef]

Dawdy, Shannon Lee. 2009. Millennial Archaeology. Locating the Discipline in the Age of Insecurity. Archaeological Dialogues 16: 131-42. [CrossRef]

Deligne, N. I., S. G. Coles, and R. S. J. Sparks. 2010. Recurrence Rates of Large Explosive Volcanic Eruptions. Journal of Geophysical Research 115: B06203. [CrossRef]

Dincauze, Dana F. 2000. Environmental Archaeology: Principles and Practice. Cambridge: Cambridge University Press.

Dix, Andreas, and Matthias Röhrs. 2007. Vergangenheit Versus Gegenwart? Anmerkungen Zu Potentialen, Risiken Und Nebenwirkungen Einer Kombination Historischer Und Aktueller Ansätze Der Naturgefahrenforschung. Historical Social Research 32: 215-34.

Donovan, Amy R., and Clive Oppenheimer. 2011. The 2010 Eyjafjallajökull Eruption and the Reconstruction of Geography. The Geographical Journal 177: 4-11. [CrossRef]

Donovan, Amy R., and Clive Oppenheimer. 2012. Governing the Lithosphere: Insights from Eyjafjallajokull Concerning the Role of Scientists in Supporting Decision-Making on Active Volcanoes. Journal of Geophysical Research Solid Earth 117. [CrossRef]

Donovan, Amy R., and Clive Oppenheimer. 2013. Managing the Uncertain Earth: Geophysical Hazards in the Risk Society. The Geographical Journal. [CrossRef]

Donovan, Amy, and Oppenheimer Clive. 2017. Imagining the Unimaginable: Communicating Extreme Volcanic Risk. In Advances in Volcanology. Edited by Karoly Nemeth. Berlin and Heidelberg: Springer, pp. 1-15.

Donovan, Amy R., Clive Oppenheimer, and Michael Bravo. 2012. The Use of Belief-Based Probabilistic Methods in Volcanology: Scientists' Views and Implications for Risk Assessments. Journal of Volcanology and Geothermal Research 247-248: 168-80. [CrossRef]

Dörries, Matthias. 2010. Climate Catastrophes and Fear. Wiley Interdisciplinary Reviews: Climate Change 1: 885-90. [CrossRef] 
Dugmore, Andrew J., Mike J. Church, Kerry-Anne Mairs, Thomas H. McGovern, Sophia Perdikaris, and Orri Vésteinsson. 2007. Abandoned Farms, Volcanic Impacts, and Woodland Management: Revisiting Pjórsárdalur, the "Pompeii of Iceland". Arctic Anthropology 44: 1-11. [CrossRef]

Dukes, Paul. 2013. Big History, Deep History and the Anthropocene. History Today 63: 4-5.

Erfurt-Cooper, Patricia. 2010. The Vulkaneifel in Germany. A Destination for Geotourism. In Volcano and Geothermal Tourism: Sustainable Geo-Resources for Leisure and Recreation. Edited by Patricia Erfurt-Cooper and Malcolm Cooper. London: Earthscan, pp. 281-85.

Evans, John G. 2002. Environmental Archaeology and the Social Order. London: Routledge.

Evans, Louisa S., Christina C. Hicks, Pedro Fidelman, Renae C. Tobin, and Allison L. Perry. 2013. Future Scenarios as a Research Tool: Investigating Climate Change Impacts, Adaptation Options and Outcomes for the Great Barrier Reef, Australia. Human Ecology 41: 841-57. [CrossRef] [PubMed]

Field, Christopher B., Vicente Barros, Thomas F. Stocker, Dahe Qin, David J. Dokken, Kirstie L. Ebi, Michael D. Mastrandrea, Katharine J. Mach, Gian-Kasper Plattner, Simon K. Allen, and et al., eds. 2012. Managing the Risks of Extreme Events and Disasters to Advance Climate Change Adaptation. Working Groups I and Ii of the Intergovernmental Panel on Climate Change, Special Report; Cambridge: Cambridge University Press.

Fisher, Richard V., and Hans-Ulrich Schmincke. 1984. Pyroclastic Rocks. Berlin: Springer.

Fuchs, Sven, Jörn Birkmann, and Thomas Glade. 2012. Vulnerability Assessment in Natural Hazard and Risk Analysis: Current Approaches and Future Challenges. Natural Hazards 64: 1969-75. [CrossRef]

Gaillard, Jean-Christophe, Francisco G. Delfin Jr., Eusebio Z. Dizon, Victor J. Paz, Emmanuel G. Ramos, Cristina T. Remotigue, Kelvin S. Rodolfo, Fernando P. Siringan, Janneli Lea S. Soria, and Jesse V. Umbal. 2007. Planning for the Future: A Multidisciplinary Approach to Reconstructing the Buag Episode of Mt Pinatubo, Phillipines. In Living under the Shadow. Cultural Impacts of Volcanic Eruptions. Edited by John Grattan and Robin Torrence. Walnut Creek: Left Coast Press, pp. 225-52.

García-Acosta, Virginia. 2002. Historical Disaster Research. In Catastrophe E Culture: The Anthropology of Disaster. Edited by Susanna M. Hoffman and Anthony Oliver-Smith. Santa Fe: School of American Research Press, pp. 49-66.

Gislason, Sigudur R., Tue Hassenkam, Sorin Nedel, Nicolas E. Bovet, Eydís S. Eiriksdottir, Helgi A. Alfredsson, Caroline P. Hem, Zolta I. Balogh, Knud Dideriksen, Noels Oskarsson, and et al. 2011. Characterization of Eyjafjallajökull Volcanic Ash Particles and a Protocol for Rapid Risk Assessment. Proceedings of the National Academy of Sciences 108: 7307-12. [CrossRef] [PubMed]

Graf, Hans-F., and Claudia Timmreck. 2001. A General Climate Model Simulation of the Aerosol Radiative Effects of the Laacher See Eruption (10,900 B.C.). Journal of Geophysical Research 106: 14747-56. [CrossRef]

Grattan, John P. 2006. Aspects of Armageddon: An Exploration of the Role of Volcanic Eruptions in Human History and Civilization. Quaternary International 151: 10-18. [CrossRef]

Grattan, John P., and Daniel J. Charman. 1994. Non-Climatic Factors and the Environmental Impact of Volcanic Volatiles: Implications of the Laki Fissure Eruption of Ad 1783. The Holocene 4: 101-6. [CrossRef]

Grattan, J., M. Durand, and S. Taylor. 2003. Illness and Elevated Human Mortality in Europe Coincident with the Laki Fissure Eruption. In Volcanic Degassing. Edited by Clive Oppenheimer, David M. Pyle and Jennifer Barclay. London: Geological Society, pp. 410-14.

Grattan, John Patrick, Sabina Michnowicz, and Roland Rabartin. 2007. The Long Shadow: Understanding the Influence of the Laki Fissure Eruption on Human Mortality in Europe. In Living under the Shadow. Cultural Impacts of Volcanic Eruptions. Edited by John Grattan and Robin Torrence. Walnut Creek: Left Coast Press, pp. 153-74.

Guiver, Jo, and Juliet Jain. 2011. Grounded: Impacts of and Insights from the Volcanic Ash Cloud Disruption. Mobilities 6: 41-55. [CrossRef]

Guttmann-Bond, Erika. 2010. Sustainability out of the Past: How Archaeology Can Save the Planet. World Archaeology 42: 355-66. [CrossRef]

Hayes, Josh L., Thomas M. Wilson, and Christina Magill. 2015. Tephra Fall Clean-up in Urban Environments. Journal of Volcanology and Geothermal Research 304: 359-77. [CrossRef]

Helbing, Dirk. 2013. Globally Networked Risks and How to Respond. Nature 497: 51-59. [CrossRef] [PubMed]

Helbing, Dirk, Hendrik Ammoser, and Christian Kühnert. 2006. Disasters as Extreme Events and the Importance of Network Interactions for Disaster Response Management. In Extreme Events in Nature and Society. Edited by Sergio Albeverio, Volker Jentsch and Holger Kantz. Berlin: Springer, pp. 319-48. 
Höfchen, Heinz, Kirsten Maria Limberg, and Christoph Zuschlag, eds. 2014. Apocalypse Now! Visionen Von Schrecken Und Hoffnung in Der Kunst Vom Mittelalter Bis Heute. München and Berlin: Deutscher Kunstverlag.

Horn, Eva. 2012. Das Wetter Von Übermorgen. Kleine Imaginationsgeschichte Der Klimakatastrophe. Merkur 12: 1091-105.

Horn, Eva. 2014. Zukunft Als Katastrophe. Frankfurt am Main: S. Fischer.

Huhtamaa, Heli, and Samuli Helama. 2017. Distant Impact: Tropical Volcanic Eruptions and Climate-Driven Agricultural Crises in Seventeenth-Century Ostrobothnia, Finland. Journal of Historical Geography 57: 40-51. [CrossRef]

Hulme, Mike. 2008. The Conquering of Climate: Discourses of Fear and Their Dissolution. Geographical Journal 174: 5-16. [CrossRef]

Janson, Uwe. 2009. Vulkan. Available online: http:/ /www.imdb.com/title/tt1266601/ (accessed on 23 October 2017).

Janssens, M. M., C. Kasse, S. J. P. Bohncke, H. Greaves, K. M. Cohen, J. Wallinga, and W. Z. Hoek. 2012. Climate-Driven Fluvial Development and Valley Abandonment at the Last Glacial-Interglacial Transition (Oude Ijssel-Rhine, Germany). Netherlands Journal of Geosciences-Geologie En Mijnbouw 91: 37-62. [CrossRef]

Johns-Putra, Adeline. 2016. Climate Change in Literature and Literary Studies: From Cli-Fi, Climate Change Theater and Ecopoetry to Ecocriticism and Climate Change Criticism. Wiley Interdisciplinary Reviews: Climate Change 7: 266-82. [CrossRef]

Kaiser, Klaus Felix. 1993. Klimageschichte Vom Späten Hochglazial Bis Ins Frühe Holozän, Rekonstruiert Mit Jahrringen Und Molluskenschalen Aus Verschiedenen Vereisungsgebieten. Zürich: Eidgenössische Forschungsanstalt für Wald, Schnee und Landschaft.

Kelman, Ilan, and Tamsin A. Mather. 2008. Living with Volcanoes: The Sustainable Livelihoods Approach for Volcano-Related Opportunities. Journal of Volcanology and Geothermal Research 172: 189-98. [CrossRef]

Kelman, Ilan, Jean-Christophe Gaillard, and Jessica Mercer. 2015. Climate Change's Role in Disaster Risk Reduction's Future: Beyond Vulnerability and Resilience. International Journal of Disaster Risk Science 6: 21-27. [CrossRef]

Kelman, Ilan, Jessica Mercer, and Jean-Christophe Gaillard, eds. 2017. The Routledge Handbook of Disaster Risk Reduction Including Climate Change Adaptation. Routledge International Handbooks. Abingdon: Routledge.

Kieffer, Susan W. 2013. The Dynamics of Disaster, 1st ed. New York: W. W. Norton \& Co.

Krämer, Daniel. 2009. Sie Haben Festgestellt, Dass Es Keinen Sommer Gegeben Hat. Der Ausbruch Des Tambora (Indonesien) Am 10. April 1815 Und Seine Auswirkungen. In Katastrophen. Vom Untergang Pompejis Bis Zum Klimawandel. Edited by Gerrit J. Schenk. Ostfildern: Jan Thorbecke Verlag, pp. 132-46.

Langmann, Baerbel, Arnau Folch, Martin Hensch, and Volker Matthias. 2012. Volcanic Ash over Europe During the Eruption of Eyjafjallajökull on Iceland, April-May 2010. Atmospheric Environment 48: 1-8. [CrossRef]

Leder, Jan, Friedemann Wenzel, James E. Daniell, and Ellen Gottschämmer. 2017. Loss of Residential Buildings in the Event of a Re-Awakening of the Laacher See Volcano (Germany). Journal of Volcanology and Geothermal Research 337: 111-23. [CrossRef]

Lovekamp, William E., and Joseph E. Trainor. 2013. 30 Years of Dissertation Trends in Disaster Studies. HazNet 5: 11-14.

Lowe, David J., Rewi M. Newnham, and John D. McCraw. 2002. Volcanism and Early Maori Society in New Zealand. In Natural Disasters and Cultural Change. Edited by Robin Torrence and John Grattan. London: Routledge, pp. 126-61.

Lowe, John J., Sune O. Rasmussen, Svante Björck, Wim Z. Hoek, Jørgen P. Steffensen, Mike J. C. Walker, C. Yu, and the INTIMATE group. 2008. Synchronisation of Palaeoenvironmental Events in the North Atlantic Region During the Last Termination: A Revised Protocol Recommended by the Intimate Group. Quaternary Science Reviews 27: 6-17. [CrossRef]

Luhr, James F., and Tom Simkin. 1993. Parícutin: The Volcano Born in a Mexican Cornfield. Phoenix: Geoscience Press.

Lund, Katrín Anna, and Karl Benediktsson. 2011. Inhabiting a Risky Earth: The Eyjafjallajökull Eruption in 2010 and Its Impacts. Anthropology Today 27: 6-9. [CrossRef]

Luterbacher, Jürg, and Christian Pfister. 2015. The Year without a Summer. Nature Geosci 8: 246-48. [CrossRef]

Malm, Andreas, and Alf Hornborg. 2014. The Geology of Mankind? A Critique of the Anthropocene Narrative. The Anthropocene Review 1: 62-69. [CrossRef]

Mason, Ben G., David M. Pyle, and Clive Oppenheimer. 2004. The Size and Frequency of the Largest Explosive Eruptions on Earth. Bulletin of Volcanology 66: 735-48. [CrossRef] 
Mastrolorenzo, Giuseppe, Pierpaolo Petrone, Lucia Pappalardo, and Michael F. Sheridan. 2006. The Avellino 3780-Yr-B.P. Catastrophe as a Worst-Case Scenario for a Future Eruption at Vesuvius. Proceedings of the National Academy of Sciences of the United States of America 103: 4366-70. [CrossRef] [PubMed]

Mathews, Andrew S., and Jessica Barnes. 2016. Prognosis: Visions of Environmental Futures. Journal of the Royal Anthropological Institute 22: 9-26. [CrossRef]

Mauelshagen, Franz. 2009. Die Klimakatastrophe. Szenen Und Szenarien. In Katastrophen. Vom Untergang Pompejis Bis Zum Klimawandel. Edited by Gerrit J. Schenk. Ostfildern: Jan Thorbecke Verlag, pp. 205-23.

Mazzorana, Bruno, Johannes Hübl, and Sven Fuchs. 2009. Improving Risk Assessment by Defining Consistent and Reliable System Scenarios. Natural Hazards and Earth System Science 9: 145-59. [CrossRef]

McCormick, Michael, Paul Edward Dutton, and Paul A. Mayewski. 2007. Volcanoes and the Climate Forcing of Carolingian Europe, A.D. 750-950. Speculum 82: 865-95. [CrossRef]

McGuire, W. J. 2013. Waking the Giant: How a Changing Climate Triggers Earthquakes, Tsunamis, and Volcanoes. Oxford: Oxford University Press.

Mercer, Jessica, Jean-Christophe Gaillard, Katherine Crowley, Rachel Shannon, Bob Alexander, Simon Day, and Julia Becker. 2012. Culture and Disaster Risk Reduction: Lessons and Opportunities. Environmental Hazards 11: 74-95. [CrossRef]

Michel-Kerjan, Erwann. 2012. How Resiliant Is Your Country? Nature 491: 497. [CrossRef] [PubMed]

Middleton, Guy. 2012. Nothing Lasts Forever: Environmental Discourses on the Collapse of Past Societies. Journal of Archaeological Research 20: 257-307. [CrossRef]

Middleton, Guy. 2013. That Old Devil Called Collapse. E-International Relations, Feberary 6. Available online: http:/ / www.e-ir.info/2013/02/06/that-old-devil-called-collapse/ (accessed on 23 October 2017).

Mitchell, John F. B., Jason Lowe, Richard A. Wood, and Michael Vellinga. 2006. Extreme Events Due to Human-Induced Climate Change. Philosophical Transactions of the Royal Society A: Mathematical, Physical and Engineering Sciences 364: 2117-33. [CrossRef] [PubMed]

Neri, Augusto, Willy P. Aspinall, Raffaelo Cioni, Antonella Bertagnini, Peter J. Baxter, Giuilio Zuccaro, Daniele Andronico, Sara Barsotti, Paul D. Cole, Tomaso Esposti Ongaro, and et al. 2008. Developing an Event Tree for Probabilistic Hazard and Risk Assessment at Vesuvius. Journal of Volcanology and Geothermal Research 178: 397-415. [CrossRef]

Newhall, Christopher G., and Stephen Self. 1982. The Volcanic Explosivity Index (Vei): An Estimate of Explosive Magnitude for Historical Volcanism. Journal of Geophysical Research 87: 1231-38. [CrossRef]

Nielsen, Esben Bjerggaard. 2013. Klima, Apokalypse Og En Topos Om Sted. Rhetorica Scandinavica 63: 39-53.

Nikoleris, Alexandra, Johannes Stripple, and Paul Tenngart. 2017. Narrating Climate Futures: Shared Socioeconomic Pathways and Literary Fiction. Climatic Change 143: 307-19. [CrossRef]

November, V. 2008. Spatiality of Risk. Environment and Planning A 40: 1523-27. [CrossRef]

Nowell, David A.G., M.Chris Jones, and David M. Pyle. 2006. Episodic Quaternary Volcanism in France and Germany. Journal of Quaternary Science 21: 645-75. [CrossRef]

Oetelaar, Gerald Anthony. 2015. The Days of the Dry Snow: Vulnerabilities and Transformations Related to the Mazama Ash Fall on the Northern Plains. In Past Vulnerability. Volcanic Eruptions and Human Vulnerability in Traditional Societies Past and Present. Edited by Felix Riede. Aarhus: Aarhus University Press, pp. 205-28.

O'Keefe, Phil, Ken Westgate, and Ben Wisner. 1976. Taking the Naturalness out of Natural Disasters. Nature 260: 566-67. [CrossRef]

Olshansky, Robert, Lewis D. Hopkins, and Laurie A. Johnson. 2012. Disaster and Recovery: Processes Compressed in Time. Natural Hazards Review 13: 173-78. [CrossRef]

Oppenheimer, Clive. 2011. Eruptions That Shook the World. Cambridge: Cambridge University Press.

O’Regan, Michael. 2011. On the Edge of Chaos: European Aviation and Disrupted Mobilities. Mobilities 6: 21-30. [CrossRef]

Oreskes, Naomi, and Erik M. Conway. 2014. The Collapse of Western Civilization: A View from the Future. New York: Columbia University Press.

Pagli, Carolina, and Freysteinn Sigmundsson. 2008. Will Present Day Glacier Retreat Increase Volcanic Activity? Stress Induced by Recent Glacier Retreat and Its Effect on Magmatism at the Vatnajökull Ice Cap, Iceland. Geophysical Research Letters 35: L09304. [CrossRef]

Pancost, Richard D. 2017. Climate Change Narratives. Nature Geoscience 10: 466-68. [CrossRef] 
Park, Cornelia, and Hans-Ulrich Schmincke. 1997. Lake Formation and Catastrophic Dam Burst During the Late Pleistocene Laacher See Eruption (Germany). Naturwissenschaften 84: 521-25. [CrossRef]

Park, Cornelia, and Hans-Ulrich Schmincke. 2009. Apokalypse Im Rheintal. Spektrum der Wissenschaften 2009: 78-87.

Pedersen, Rikke. 2010. Eyjafjallajökull. Vulkanen Der Lammede Europa. København: Gyldendal.

Pfister, Christian. 2009a. The "Disaster Gap" of the 20th Century and the Loss of Traditional Disaster Memory. GAIA-Ecological Perspectives for Science and Society 18: 239-46. [CrossRef]

Pfister, Christian. 2009b. Learning from Nature-Induced Disasters: Theoretical Considerations and Case Studies from Western Europe. In Natural Disasters, Cultural Responses: Case Studies toward a Global Environmental History. Edited by Christof Mauch and Cristian Pfister. Lanham: Lexington Books, pp. 17-40.

Plag, Hans-Peter. 2014. Foreword: Extreme Geohazards-A Growing Threat for a Globally Interconnected Civilization. Natural Hazards 72: 1275-77. [CrossRef]

Price, Neil, and Bo Gräslund. 2015. Excavating the Fimbulwinter? Archaeology, Geomythology and the Climate Event(S) of Ad 536. In Past Vulnerability. Volcanic Eruptions and Human Vulnerability in Traditional Societies Past and Present. Edited by Felix Riede. Aarhus: Aarhus University Press, pp. 109-32.

Pyle, David M. 2000. Sizes of Volcanic Eruptions. In Encyclopedia of Volcanoes. Edited by Haraldur Sigurdsson, Bruce Houghton, Steve McNutt, Hazel Rymer and John Stix. San Diego: Academic Press, pp. 263-70.

Pyle, David M. 2017. Volcanoes: Encounters through the Ages. Oxford: Bodleian Library.

Rees, Martin. 2013. Denial of Catastrophic Risks. Science 339: 1123. [CrossRef] [PubMed]

Rees, Morien. 2017. Museums as Catalysts for Change. Nature Climate Change 7: 166-67. [CrossRef]

Riede, Felix. 2007. Der Ausbruch Des Laacher See-Vulkans Vor 12.920 Jahren Und Urgeschichtlicher Kulturwandel Am Ende Des Alleröd. Eine Neue Hypothese Zum Ursprung Der Bromme Kultur Und Des Perstunien. Mitteilungen der Gesellschaft für Urgeschichte 16: 25-54.

Riede, Felix. 2008. The Laacher See-Eruption (12,920 Bp) and Material Culture Change at the End of the Allerød in Northern Europe. Journal of Archaeological Science 35: 591-99. [CrossRef]

Riede, Felix. 2009. The Loss and Re-Introduction of Bow-and-Arrow Technology: A Case Study from the Southern Scandinavian Late Palaeolithic. Lithic Technology 34: 27-45. [CrossRef]

Riede, Felix. 2012. Tephrochronologische Nachuntersuchungen Am Endpaläolithischen Fundplatz Rothenkirchen, Kreis Fulda. Führte Der Ausbruch Des Laacher See-Vulkans (10966 V. Chr.) Zu Einer Anhaltenden Siedlungslücke in Hessen? Jahrbuch des nassauischen Vereins für Naturkunde 133: 47-68.

Riede, Felix. 2014a. Climate Models: Use Archaeology Record. Nature 513: 315. [CrossRef] [PubMed]

Riede, Felix. 2014b. Eruptions and Ruptures-A Social Network Perspective on Vulnerability and Impact of the Laacher See Eruption (C. 13,000 Bp) on Late Glacial Hunter-Gatherers in Northern Europe. Archaeological Review from Cambridge 29: 67-102.

Riede, Felix. 2014c. Towards a Science of Past Disasters. Natural Hazards 71: 335-62. [CrossRef]

Riede, Felix. 2015. 'Dominant' and 'Radical' Perspectives on Material Culture Change in the Wake of the Catastrophic Laacher See Volcanic Eruption (C. 13,000 Cal Bp) in Northern Europe. In Past Vulnerability. Volcanic Eruptions and Human Vulnerability in Traditional Societies Past and Present. Edited by Felix Riede. Aarhus: Aarhus University Press, pp. 229-56.

Riede, Felix. 2016. Changes in Mid- and Far-Field Human Landscape Use Following the Laacher See Eruption (C. 13,000 Bp). Quaternary International 394: 37-50. [CrossRef]

Riede, Felix. 2017. Splendid Isolation. The Eruption of the Laacher See Volcano and Southern Scandinavian Late Glacial Hunter-Gatherers. Aarhus: Aarhus University Press.

Riede, Felix, and Oliver Bazely. 2009. Testing the 'Laacher See Hypothesis': A Health Hazard Perspective. Journal of Archaeological Science 36: 675-83. [CrossRef]

Riede, Felix, and Jeffrey M. Wheeler. 2009. Testing the 'Laacher See Hypothesis': Tephra as Dental Abrasive. Journal of Archaeological Science 36: 2384-91. [CrossRef]

Riede, Felix, Oliver Bazely, Anthony J. Newton, and Christine S. Lane. 2011. A Laacher See-Eruption Supplement to Tephrabase: Investigating Distal Tephra Fallout Dynamics. Quaternary International 246: 134-44. [CrossRef]

Riede, Felix, Annette Højen Sørensen, Jan Dietrich, Høegsberg Skaaning, Nordvig Mogens, Valentin Mathias, and Esben Bjerggaard Nielsen. 2016a. Learning from the Past-Teaching Past Climate Change and Catastrophes as Windows onto Vulnerability and Resilience. In Teaching Climate Change in the Humanities. Edited by Stephen Siperstein, Stephanie Lemenager and Shane Hall. New York: Routledge, pp. 126-35. 
Riede, Felix, Per Andersen, and Neil Price. 2016b. Does Environmental Archaeology Need an Ethical Promise? World Archaeology 48: 466-81. [CrossRef]

Rissland, Edwina L. 2009. Black Swans, Gray Cygnets and Other Rare Birds. In Case-Based Reasoning Research and Development. Edited by Lorraine McGinty and David C. Wilson. Berlin and Heidelberg: Springer, pp. 6-13.

Rockman, Marcy. 2012. The Necessary Roles of Archaeology in Climate Change Mitigation and Adaptation. In Archaeology in Society. Edited by Marcy Rockman and Joe Flatman. New York: Springer, pp. 193-215.

Rounsevell, Mark D. A., and Marc J. Metzger. 2010. Developing Qualitative Scenario Storylines for Environmental Change Assessment. Wiley Interdisciplinary Reviews: Climate Change 1: 606-19. [CrossRef]

Scanlon, Joseph. 1988. Winners and Losers: Some Thoughts About the Political Economy of Disaster. International Journal of Mass Emergencies and Disasters 6: 47-63.

Schenk, Gerrit J. 2015. 'Learning from History'? Chances, Problems and Limits of Learning from Historical Natural Disasters. In Cultures and Disasters. Understanding Cultural Framings in Disaster Risk Reduction. Edited by Fred Krüger, Greg Bankoff, Terry Cannon, Benedikt Orlowski and Lisa E. Schipper. London: Routledge, pp. 72-87.

Gerrit J. Schenk, Monica Juneja, Alfried Wieczorek, and Christoph Lind, eds. 2014. Von Atlantis Bis Heute-Mensch. Natur. Katastrophe. Schnell und Steiner: Regensburg.

Schiermeier, Quirin. 2011. Climate and Weather: Extreme Measures. Nature 477: 148-49. [CrossRef] [PubMed]

Schiermeier, Quirin. 2012. Disaster Toll Tallied. Nature 481: 124-25. [CrossRef] [PubMed]

Schmidt, Anja, Bart Ostro, Kenneth S. Carslaw, Marjorie Wilson, Thorvaldur Thordarson, Graham W. Mann, and Adrian J. Simmons. 2011. Excess Mortality in Europe Following a Future Laki-Style Icelandic Eruption. Proceedings of the National Academy of Sciences 108: 15710-15. [CrossRef] [PubMed]

Schmincke, Hans-Ulrich. 2004. Volcanism. Berlin: Springer.

Schmincke, Hans-Ulrich. 2006. Environmental Impacts of the Lateglacial Eruption of the Laacher See Volcano, 12,900 Cal Bp. In 150 Years of Neanderthal Discoveries. Edited by W. von Koenigswald and T. Litt. Bonn: Terra Nostra, pp. 149-53.

Schmincke, Hans-Ulrich, Cornelia Park, and Eduard Harms. 1999. Evolution and Environmental Impacts of the Eruption of Laacher See Volcano (Germany) 12,900 a Bp. Quaternary International 61: 61-72. [CrossRef]

Schreiber, Ulrich C. 2006. Die Flucht Der Ameisen. München and Zürich: Piper.

Siebert, Lee, Tom Simkin, and Paul Kimberly. 2010. Volcanoes of the World, 3rd ed. Edited by Lee Siebert, Tom Simkin and Paul Kimberly. Washington: Smithsonian Institution.

Sigmundsson, Freysteinn, Virginie Pinel, Björn Lund, Fabien Albino, Carolina Pagli, Halldór Geirsson, and Erik Sturkell. 2010. Climate Effects on Volcanism: Influence on Magmatic Systems of Loading and Unloading from Ice Mass Variations, with Examples from Iceland. Philosophical Transactions of the Royal Society A: Mathematical, Physical and Engineering Sciences 368: 2519-34. [CrossRef] [PubMed]

Small, Christopher, and Terry Naumann. 2001. The Global Distribution of Human Population and Recent Volcanism. Environmental Hazards 3: 93-109. [CrossRef]

Smit, Barry, and Johanna Wandel. 2006. Adaptation, Adaptive Capacity and Vulnerability. Global Environmental Change 16: 282-92. [CrossRef]

Smith, Joel B., Stephen H. Schneider, Michael Oppenheimer, Gary W. Yohe, William Hare, Michael D. Mastrandrea, Anand Patwardhan, Ian Burton, Jan Corfee-Morlot, Chris H. D. Magadza, and et al. 2009. Assessing Dangerous Climate Change through an Update of the Intergovernmental Panel on Climate Change (Ipcc) "Reasons for Concern". Proceedings of the National Academy of Sciences 106: 4133-37. [CrossRef] [PubMed]

Smolka, Anselm. 2006. Natural Disasters and the Challenge of Extreme Events: Risk Management from an Insurance Perspective. Philosophical Transactions of the Royal Society A: Mathematical, Physical and Engineering Sciences 364: 2147. [CrossRef] [PubMed]

Solnit, Rebecca. 2010. A Paradise Built in Hell: The Extraordinary Communities That Arise in Disaster. London: Penguin. Sommer, Ulrike. 2000. Archaeology and Regional Identity in Saxony. Public Archaeology 1: 125-42. [CrossRef]

Sonnek, Karin Mossberg, Tomas Mårtensson, Ester Veibäck, Peter Tunved, Håkan Grahn, Pontus von Schoenberg, Niklas Brännström, and Anders Bucht. 2017. The Impacts of a Laki-Like Eruption on the Present Swedish Society. Natural Hazards 88: 1565-90. [CrossRef]

Sparks, Steve. 2007. Use the Calm between the Storms. Nature 450: 354-54. [CrossRef] [PubMed]

Staley, David J. 2002. A History of the Future. History and Theory 41: 72-89. [CrossRef] 
Stein, Jerome L., and Seth Stein. 2014. Gray Swans: Comparison of Natural and Financial Hazard Assessment and Mitigation. Natural Hazards 72: 1279-97. [CrossRef]

Stewart, Iain S., and Deirdre Lewis. 2017. Communicating Contested Geoscience to the Public: Moving from 'Matters of Fact' to 'Matters of Concern'. Earth-Science Reviews. [CrossRef]

Stott, Peter A., Nikolaos Christidis, Friederike E. L. Otto, Ying Sun, Jean-Paul Vanderlinden, Geert Jan van Oldenborgh, Robert Vautard, Hans von Storch, Peter Walton, Pascal Yiou, and et al. 2016. Attribution of Extreme Weather and Climate-Related Events. Wiley Interdisciplinary Reviews: Climate Change 7: $23-41$. [CrossRef] [PubMed]

Street, Martin. 1986. Ein Wald Der Allerödzeit Bei Miesenheim, Stadt Andernach (Neuwieder Becken). Archäologisches Korrespondenzblatt 16: 13-22.

Stump, Daryl. 2013. On Applied Archaeology, Indigenous Knowledge, and the Usable Past. Current Anthropology 54: 268-98. [CrossRef]

Susman, Paul, Phil O'Keefe, and Ben Wisner. 1983. Global Disasters, a Radical Interpretation. In Interpretations of Calamity. Edited by Kenneth Hewitt. London: Allen \& Unwin, pp. 263-83.

Tainter, Joseph A. 2008. Collapse, Sustainability, and the Environment: How Authors Choose to Fail or Succeed. Reviews in Anthropology 37: 342-71. [CrossRef]

Taleb, Nassim. 2010. The Black Swan: The Impact of the Highly Improbable, 2nd ed. London: Penguin.

Thordarson, Thorvaldur, and Gudrun Larsen. 2007. Volcanism in Iceland in Historical Time: Volcano Types, Eruption Styles and Eruptive History. Journal of Geodynamics 43: 118-52. [CrossRef]

Thorvaldsdóttir, Sólveig, and Ragnar Sigbjörnsson. 2015. Framing the 2010 Eyjafjallajökull Volcanic Eruption from a Farming-Disaster Perspective. Natural Hazards 77: 1619-53. [CrossRef]

Tierney, Kathleen J. 2014. The Social Roots of Risk. Redwood City: Stanford University Press.

Toohey, Matthew, Kirstin Krüger, Michael Sigl, Frode Stordal, and Henrik Svensen. 2016. Climatic and Societal Impacts of a Volcanic Double Event at the Dawn of the Middle Ages. Climatic Change 136: 401-12. [CrossRef]

Robin Torrence, and John Grattan, eds. 2002. Natural Disasters and Cultural Change. One World Archaeology; London: Routledge.

Uehlinger, Urs, Karl M. Wantzen, and Rob S. E. W. Leuven. 2009. The Rhine River Basin. In Rivers of Europe. Edited by Klement Trockner, Urs Uehlinger and Christopher T. Robinson. London: Academic Press, pp. 199-245.

Urry, John. 2007. Mobilities. Cambridge: Polity Press.

Urry, John. 2009. Aeromobilities and the Global. In Aeromobilities. Edited by Saulo Cwerner, Sven Kesselring and John Urry. New York: Routledge, pp. 25-37.

Van Bavel, Bas, and Daniel R. Curtis. 2016. Better Understanding Disasters by Better Using History: Systematically Using the Historical Record as One Way to Advance Research into Disasters. International Journal of Mass Emergencies and Disasters 34: 143-69.

Van de Noort, Robert. 2011. Conceptualising Climate Change Archaeology. Antiquity 85: 1039-48. [CrossRef]

Van de Noort, Robert. 2013. Climate Change Archaeology: Building Resilience from Research in the World's Coastal Wetlands. Oxford: Oxford University Press.

Van den Bogaard, P. 1995. ${ }^{40} \mathrm{ar} /{ }^{39}$ ar Ages of Sanidine Phenocrysts from Laacher See Tephra (12,900 Yr Bp): Chronostratigraphic and Petrological Significance. Earth and Planetary Science Letters 133: 163-74. [CrossRef]

Van den Bogaard, P., and Hans-Ulrich Schmincke. 1984. The Eruptive Center of the Late Quaternary Laacher See Tephra. Geologische Rundschau 73: 933-80. [CrossRef]

Van den Bogaard, P., and Hans-Ulrich Schmincke. 1985. Laacher See Tephra: A Widespread Isochronous Late Quaternary Tephra Layer in Central and Northern Europe. Geological Society of America Bulletin 96: 1554-71. [CrossRef]

Van den Bogaard, Paul, Hans-Ulrich Schmincke, Armin Freundt, and Cornelia Park. 1990. Evolution of Complex Plinian Eruptions: The Late Quaternary Laacher See Case History. In Thera and the Aegean World III. Volume 2: Earth Sciences. Edited by David A. Hardy, Jörg Keller, Vassilis P. Galanopoulos, Nicholas C. Flemming and Tim H. Druitt. London: The Thera Foundation, pp. 463-83.

Van Raden, Ulrike J., Daniele Colombaroli, Adrian Gilli, Jakob Schwander, Stefano M. Bernasconi, Jacqueline van Leeuwen, Markus Leuenberger, and Ueli Eicher. 2013. High-Resolution Late-Glacial Chronology for the Gerzensee Lake Record (Switzerland): $\Delta^{18} \mathrm{o}$ Correlation between a Gerzensee-Stack and Ngrip. Palaeogeography, Palaeoclimatology, Palaeoecology 391: 13-24. [CrossRef] 
Von Berg, Axel. 1994a. Allerödzeitliche Feuerstellen Unter Dem Bims Im Neuwieder Becken (Rheinland-Pfalz). Archäologisches Korrespondenzblatt 24: 355-65.

Von Berg, Axel. 1994b. Lebensspuren in Der Quartären Vulkanasche Der Osteifel Bei Mertloch. Archäologie in Deutschland 1994: 50-51.

White, Gilbert F. 1974. Natural Hazards Research: Concepts, Methods and Policy Implications. In Natural Hazards: Local, National, Global. Edited by Gilbert F. White. Oxford: Oxford University Press, pp. 3-16.

Wilson, Thomas M., Susanna Jenkins, and Carol Stewart. 2015. Impacts from Volcanic Ash Fall. In Volcanic Hazards, Risks and Disasters. Edited by Paolo Papale. Boston: Elsevier, pp. 47-86.

Wisner, Ben, Piers Blaikie, Terry Cannon, and Ian Davis. 2004. At Risk. Natural Hazards, People's Vulnerability and Disasters, 2nd ed. London: Routledge.

Witham, Claire S. 2005. Volcanic Disasters and Incidents: A New Database. Journal of Volcanology and Geothermal Research 148: 191-233. [CrossRef]

(C) 2017 by the author. Licensee MDPI, Basel, Switzerland. This article is an open access article distributed under the terms and conditions of the Creative Commons Attribution (CC BY) license (http:/ / creativecommons.org/licenses/by/4.0/). 